\title{
Translational Animal Models Provide Insight Into Mesenchymal Stromal Cell (MSC) Secretome Therapy
}

\author{
Rebecca M. Harmant, Charlotte Marx ${ }^{\dagger}$ and Gerlinde R. Van de Walle* \\ Baker Institute for Animal Health, College of Veterinary Medicine, Cornell University, Ithaca, NY, United States
}

The therapeutic potential of the mesenchymal stromal cell (MSC) secretome, consisting of all molecules secreted by MSCs, is intensively studied. MSCs can be readily isolated, expanded, and manipulated in culture, and few people argue with the ethics of their collection. Despite promising pre-clinical studies, most MSC secretome-based therapies have not been implemented in human medicine, in part because the complexity of bioactive factors secreted by MSCs is not completely understood. In addition, the MSC

OPEN ACCESS

Edited by:

Joan Oliva,

Emmaus Medical, Inc., United States

Reviewed by:

Anastasia Efimenko,

Lomonosov Moscow State University,

Russia

Borhane Guezguez,

German Cancer Consortium, German Cancer Research Center (DKFZ),

Germany

*Correspondence:

Gerlinde R. Van de Walle

grv23@cornell.edu

tThese authors have contributed equally to this work

Specialty section:

This article was submitted to

Stem Cell Research,

a section of the journal

Frontiers in Cell and Developmental

Biology

Received: 17 January 2021 Accepted: 01 March 2021

Published: 19 March 2021

Citation:

Harman RM, Marx C and Van de Walle GR (2021) Translational Animal Models Provide Insight Into Mesenchymal Stromal Cell (MSC)

Secretome Therapy. Front. Cell Dev. Biol. 9:654885. doi: 10.3389/fcell.2021.654885 secretome is variable, influenced by individual donor, tissue source of origin, culture conditions, and passage. An increased understanding of the factors that make up the secretome and the ability to manipulate MSCs to consistently secrete factors of biologic importance will improve MSC therapy. To aid in this goal, we can draw from the wealth of information available on secreted factors from MSC isolated from veterinary species. These translational animal models will inspire efforts to move human MSC secretome therapy from bench to bedside.

Keywords: mesenchymal stromal cells, stem cells, secretome, human, veterinary, translational models

\section{INTRODUCTION}

Mesenchymal stromal cells (MSCs) are adult multipotent progenitor cells found in many organs and tissue types. Due to their relative ease of isolation and expansion in culture, combined with the lack of ethical constraints associated with the collection and manipulation of embryonic stem cells, MSCs hold great promise as a multi-faceted cell-based therapy (Pittenger et al., 2019). Originally considered as whole-cell therapy, whereby injected MSCs migrate to the site of tissue damage and differentiate into cells needed for repair or regeneration, it is now accepted that transplanted MSCs do not survive for long and that the effects of MSC-based therapies are due to a broad array of secreted bioactive factors, collectively referred to as the secretome (Maguire, 2013; Moll et al., 2020; Wu et al., 2020). The recognition that MSC secreted factors are responsible for the positive effects of MSCs on tissue repair is significant, as it spurs the design of MSC-based therapies that do not require administration of the cells themselves, thus avoiding negative immune reactions or unwanted tumor growth (Sun et al., 2019).

The secretome of cells in general, is a commixture of soluble factors as well as molecules associated with extracellular vesicles (EV); lipid bilayer delimited particles of various sizes and complexities containing proteins and nucleic acids released from cells into the extracellular space. Soluble factors, such as nucleic acids, proteins, and lipids, can all be detected in the cellular secretome, at various concentrations and activity levels determined by cell type and environment (Daneshmandi et al., 2020). The human MSC secretome is no exception and has been characterized as containing EV (Gowen et al., 2020), a multitude of regulatory non-coding RNAs (Harrell et al., 2019), as well as an abundance of proteins including growth factors, cytokines, peptides, 
and hormones (Abbasi-Malati et al., 2018). Lipid mediators are less well documented but have been described as active factors released by human MSC (Vasandan et al., 2016) (Figure 1). A solid understanding of the individual bioactive factors secreted by MSCs that affect injured target cells or tissues is indispensable to refine MSC secretome-based therapies and is not contradictory to evidence that cell free-based treatments greatly benefit from the administration of the complete secretome (Eleuteri and Fierabracci, 2019; Daneshmandi et al., 2020).

The MSC secretome has been actively explored for over 25 years (Haynesworth et al., 1996) but despite promising preliminary studies, no MSC secretome-based therapies are approved by the United States Food and Drug administration (FDA) for use in human medicine. This is in part because the secretome is not definitively characterized and typically varies significantly between MSC cultures dependent on individual donor, tissue source of origin, culture conditions, and passage (Rizk et al., 2016). To (i) help define the MSC secretome, (ii) understand which molecules secreted by MSCs are therapeutically valuable, and (iii) learn how to manipulate MSC to preferentially secrete these molecules, we can take advantage of information obtained from studies of MSCs isolated from veterinary species, many of which are relevant translational models for human conditions. The wealth of reports describing the activity of specific factors secreted by MSCs from veterinary species, as well the manipulation of these MSC to secrete factors of biological interest, will benefit human medicine by expanding the general knowledge of MSCs. And, by virtue of the fact that many veterinary species suffer from diseases that are physiologically analogous to human conditions that could be treated with MSC-secreted factors, they serve as relevant translational models.

This review starts with a brief overview of secreted factors from naïve human MSCs and laboratory rodent MSCs, which historically have been considered well-accepted animal models for human research. This is followed by a review of studies in which human or laboratory rodent MSCs were manipulated to improve inherent properties to optimize the therapeutic benefits of MSC secreted factors. Next, we provide an extensive overview of studies on the secretome of naïve, as well as manipulated, MSCs isolated from veterinary species, which function as physiologically relevant translational models for human MSC secretome-based therapies but are less well accepted.

\section{THE SECRETOME OF MESENCHYMAL STROMAL CELLS (MSCs) FROM HUMANS AND LABORATORY RODENTS}

\section{Naïve Human MSCs}

The secretome of human MSCs regulates a wide variety of physiological processes. The pioneering studies of the effects of these secreted factors on specific target cells or in experimental rodent models have been extensively reviewed elsewhere (Vizoso et al., 2017; Abbasi-Malati et al., 2018; Eljarrah et al., 2019; Harrell et al., 2019). To provide an overview of the research conducted on human MSC secreted factors without being redundant, Table 1 summarizes human MSC secretome studies that have been published in more recent years (2018-2020). The majority of these studies evaluates either the effects of the complete secretome or exosomes (EXOs), a class of EV. An advantage to delivering MSC-secreted factors as EXOs is that EXOs can cross physiological barriers in vivo, which makes them attractive as treatments for diseases in tissues with restricted drug access such as the retina or the central nervous system (CNS) (AlvarezErviti et al., 2011; Zhang et al., 2015). Many of the studies do not identify the specific MSC secreted factors that mediate the observed effects on target cells or tissues, which illustrates the difficulty of determining precisely which factors in the complex secretome are responsible for biological responses.

\section{Naïve Rodent MSCs}

As relatively inexpensive, well-accepted models for human disease, rats and mice have been used for evaluating MSC-based therapies for human diseases. Of the many published rodent MSC studies, Table 2 gives an overview of recent work (2013-2018) focused specifically on MSC secretome components. As with the human studies, the results tend to promote the utility of the entire secretome and/or or EXOs, as opposed to confirming the specific molecules responsible for the observed biological effects.

\section{Manipulated MSCs}

Although it is clear that MSCs have great therapeutic potential and are being explored in multiple medical fields, results are often inconsistent and (pre-)clinical studies show only minor effects or do not lead to the desired outcomes at all (Lukomska et al., 2019; Wilson et al., 2019). A potential reason for the observed inconsistencies is the heterogeneity of cultured MSCs, which is influenced by the individual donor and tissue of origin, isolation technique, culture environment, and cell passage number (Wilson et al., 2019; Harman et al., 2020). Purposefully manipulating MSCs to improve therapeutic benefits, which by default could result in a more standardized and/or customized secretome, is not a novel idea, but one that has not yet been maximally explored (Liesveld et al., 2020; Ocansey et al., 2020).

The methods by which MSCs are manipulated to control secretome components broadly fall into two categories: (i) priming and (ii) genetic modification (Figure 2). Priming MSCs to improve their immunomodulatory properties, migratory potential, and/or hypo-immunogenicity, has become a field of intense research. The most popular strategies for priming include treatment with pharmacological or chemical agents, stimulation with cytokines, alterations of culture conditions via use of bio-scaffolds and/or 3D cultures, and the use of hypoxic culture conditions (Figure 2). The various strategies to influence human MSC behavior via priming have been reviewed in detail recently (Noronha et al., 2019). Genetic modification of MSCs to silence or overexpress genes of interest via transfection and/or transduction is gaining increased attention (Figure 2). Transfection approaches include microinjection, electroporation, and nanocarriers (including polymers, lipids, polysaccharides, peptides, and inorganic materials) (Hamann et al., 2019). Transduction, using viral vectors such as lentivirus 


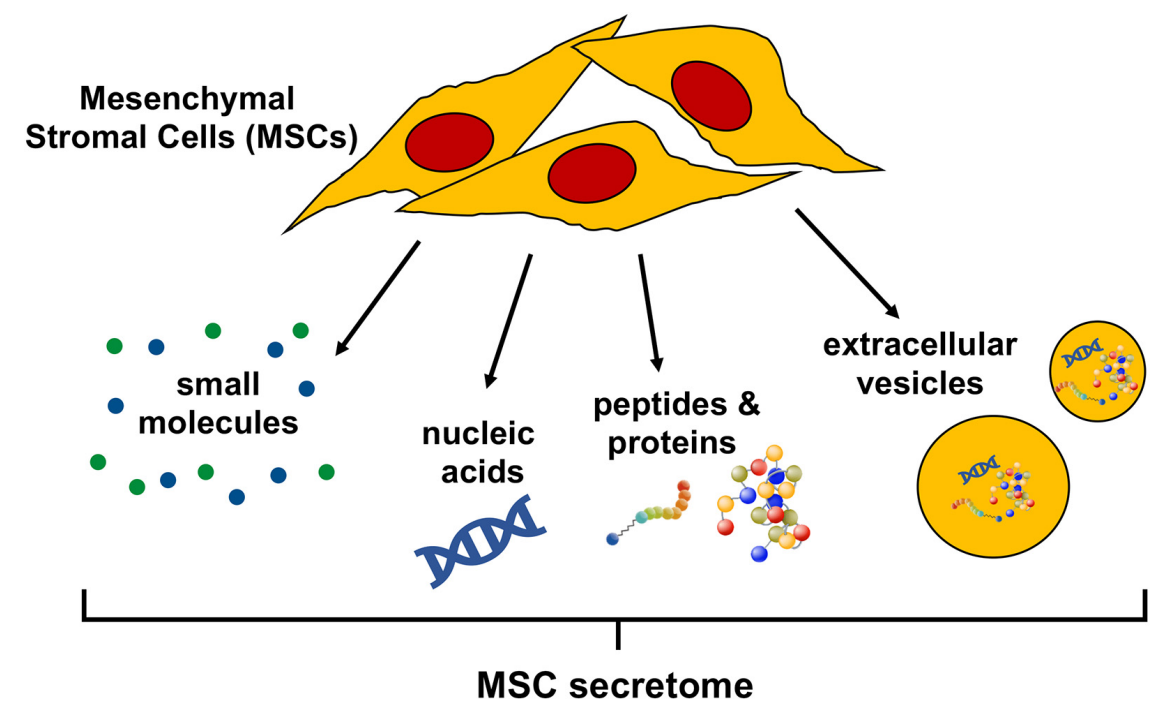

FIGURE 1 | Bioactive components of the mesenchymal stromal cell (MSC) secretome. The MSC secretome is comprised of all factors secreted by MSCs. The bioactive components of the secretome include a wide range of small molecules, nucleic acids (importantly, regulatory RNAs), peptides, and proteins. These molecules can either be released freely or packaged in extracellular vesicles, which are lipid bilayer-delimited particles of various size and composition.

and adenovirus, has the advantage of being more efficient than transfection, however, safety concerns related to potential immunogenicity and mutagenicity of the viral vectors are disadvantages of this technique for clinical use. MSCs secrete miRNAs, which are short oligonucleotides with critical posttranscriptional regulatory functions that are either released within EV or protein-associated, where miRNAs are vesiclefree but associated with high-density lipoproteins or Argonaute2/nucleophosmin-1 (Chen et al., 2012). Overexpressing or inhibiting miRNAs in MSCs is considered a valuable approach to improve clinical outcome (He and Hannon, 2004; Yeo et al., 2013) (Figure 2).

A potential, albeit minimally explored at present, method of manipulating the MSC secretome is via the exogenous bioengineering of isolated EVs. Approaches to bioengineer EVs secreted from various cell types and their therapeutic applications are the topic of a recent review (Wiklander et al., 2019). While these methods have not been widely used for MSC-derived EVs, they could become an interesting approach to control the composition of bioactive factors in the MSC secretome.

\section{Manipulated Human MSCs}

The manipulation of human MSCs to enhance secretion of desired factors, to increase homing abilities, and/or to decrease their immunogenicity, has been reviewed in depth by other authors (Najar et al., 2019; Costa et al., 2020; Ullah et al., 2019). Here, we will give a short overview of recent studies in which human MSCs have been manipulated either by priming or genetic engineering (Table 3). Of note is that studies of human MSCs are usually conducted in vitro. In order to investigate the effects of manipulated MSC in vivo, researchers typically fall back on laboratory rodent models, as outlined below, raising the question of direct translation from mice to men. As an exception, pilot studies and clinical trials have been conducted in humans using MSC for gene-directed enzyme/prodrug therapy (GDEPT) (von Einem et al., 2017, 2019). With the GDEPT approach, MSCs are solely used as vehicles to carry cargo, which consists of enzymes capable to activate the prodrug form of chemotherapeutics, into tumors. The fact that the administered inactive prodrug gets converted by the enzymes at the tumor site offers the advantage that the complete anti-tumor effect of the chemotherapeutic only unfolds locally without causing severe side effects systemically (Matuskova et al., 2015).

\section{Manipulated Rodent MSCs}

Laboratory rodent models are the gold standard for investigating the effects of manipulated MSCs in vivo. Advantages of these models are the relatively low cost, the availability of genetically modified animals designed to model human diseases, and the availability of commercially customized reagents for the use of research in rodents. Since it is common to use rodents for in vivo research, experimental work in vitro with optimized human MSCs is often followed up by related in vivo studies using rodent MSCs in experimentally induced disease models. Table 4 gives an overview of recent studies testing the efficacy of manipulated rodent MSC.

\section{THE SECRETOME OF MESENCHYMAL STROMAL CELLS (MSCs) FROM VETERINARY SPECIES}

\section{Translational Potential of MSC Research in Veterinary Species}

Mesenchymal stromal cells derived from veterinary species have been isolated, characterized and extensively studied in vitro, with 
TABLE 1 | Human MSC secretome components, targets, effects, and potential therapeutic uses.

\begin{tabular}{|c|c|c|c|c|}
\hline MSC source & Secretome components & Targets: effects & Therapeutic use & References \\
\hline Bone marrow & $\begin{array}{l}\text { Complete secretome } \\
\text { including VEGFC, TGF- } \beta 1 \text {, } \\
\text { TGF- } \beta 2 \text {, GDF6 }\end{array}$ & Secretome not tested with targets in a model system & $\begin{array}{l}\text { Hematological } \\
\text { malignancies }\end{array}$ & Baberg et al., 2019 \\
\hline Adipose & $\begin{array}{l}\text { EV derived } \\
\text { alpha-1-antitrypsin }\end{array}$ & $\begin{array}{l}\text { S. aureus, K. pneumoniae, P. aeruginosa: microbicidal } \\
\text { effect on gram negative bacteria }\end{array}$ & Pulmonary disease & Bari et al., 2019 \\
\hline $\begin{array}{l}\text { Umbilical cord, dental } \\
\text { pulp }\end{array}$ & Complete secretome & $\begin{array}{l}\text { HUVEC: decreased apoptosis and senescence, } \\
\text { increased migration, tube formation, in vitro } \\
\text { vascularization }\end{array}$ & $\begin{array}{l}\text { General MSC based } \\
\text { therapies }\end{array}$ & Caseiro et al., 2019 \\
\hline Umbilical cord & $\begin{array}{l}\text { TSG- } 6 \text { in complete CM, } \\
\text { EXO }\end{array}$ & $\begin{array}{l}\text { Newborn mouse model of BPD: improvement of lung, } \\
\text { cardiac, and brain pathology }\end{array}$ & $\begin{array}{l}\text { Bronchopulmonary } \\
\text { dysplasia }\end{array}$ & $\begin{array}{l}\text { Chaubey et al., } \\
2018\end{array}$ \\
\hline Adipose & Complete secretome & $\begin{array}{l}\text { Arsenic injured human neurons: prevent arsenic } \\
\text { induced damage }\end{array}$ & $\begin{array}{l}\text { Prevention of arsenic } \\
\text { induced toxicity }\end{array}$ & Curtis et al., 2018 \\
\hline $\begin{array}{l}\text { Hoffa's fat pad, } \\
\text { synovial membrane, } \\
\text { umbilical cord, } \\
\text { cartilage }\end{array}$ & $\begin{array}{l}\text { Complete secretome } \\
\text { including MMPs, IL-17, } \\
\text { complement factors, } \\
\text { TGF- } \beta 1 \text { and PGE2 }\end{array}$ & $\begin{array}{l}\text {-Human PBMC: inhibition of proliferation, migration and } \\
\text { cytokine secretion -Human chondrocytes: increased } \\
\text { aggrecan gene expression }\end{array}$ & $\begin{array}{l}\text { Articular cartilage } \\
\text { repair }\end{array}$ & Islam et al., 2019 \\
\hline $\begin{array}{l}\text { Adipose, bone } \\
\text { marrow, Wharton's } \\
\text { jelly }\end{array}$ & Complete secretome & $\begin{array}{l}\text {-Human monocyte: increased migration -Human } \\
\text { macrophage: increased differentiation -Human } \\
\text { endothelial cells: induced pro-angiogenic phenotype } \\
\text {-Murine vasculature: increased vascularization in } \\
\text { Matrigel plug assay }\end{array}$ & Ischemic diseases & Kehl et al., 2019 \\
\hline Bone marrow & $\begin{array}{l}\text { Complete secretome } \\
\text { including IL-5, IL-6, IL-8, } \\
\text { IL-9, IP-10 MCP-1, FGF-2 } \\
\text { and VEGF }\end{array}$ & $\begin{array}{l}\text { Human keratinocytes in hypoxic, low serum culture: } \\
\text { increased migration and proliferation, cell spreading and } \\
\text { F-actin expression }\end{array}$ & Chronic wounds & Kosol et al., 2020 \\
\hline Umbilical cord & Complete secretome & $\begin{array}{l}\text {-Rat bone marrow MSC from aged animals: increased } \\
\text { cell growth, differentiation, potential, decreased } \\
\text { senescence -Aged rats: improved bone formation } \\
\text { capacity }\end{array}$ & $\begin{array}{l}\text { Age-related } \\
\text { osteoporosis }\end{array}$ & Liang et al., 2019 \\
\hline Bone marrow & miR-21-5p from EXO & $\begin{array}{l}\text { Human engineered cardiac tissue: increased } \\
\text { contractility, calcium handling }\end{array}$ & Cardiac therapies & $\begin{array}{l}\text { Mayourian et al., } \\
2018\end{array}$ \\
\hline Bone marrow & $\begin{array}{l}\text { Complete secretome } \\
\text { including EXO-related } \\
\text { proteins related to the } \\
\text { ubiquitin-proteosome and } \\
\text { histone systems }\end{array}$ & $\begin{array}{l}\text { Human neural progenitors: induced neural } \\
\text { differentiation Rat model of Parkinson's disease: } \\
\text { rescued dopamine neurons, increased behavioral } \\
\text { performance in staircase test }\end{array}$ & Parkinson's disease & $\begin{array}{l}\text { Mendes-Pinheiro } \\
\text { et al., } 2019\end{array}$ \\
\hline Adipose & $\begin{array}{l}\text { Complete secretome, } \\
\text { soluble factors and EV } \\
\text { cargo including proteins } \\
\text { involved in RNA } \\
\text { metabolism and miRNAs } \\
\text { targeting processes } \\
\text { involved in regeneration, } \\
\text { regulation of inflammation }\end{array}$ & $\begin{array}{l}\text {-Human and rat cell lines: increased proliferation and } \\
\text { differentiation, protection against senescence -Mouse } \\
\text { model of skeletal muscle injury: enhanced rate of } \\
\text { regeneration after acute damage }\end{array}$ & Muscle regeneration & Mitchell et al., 2019 \\
\hline Adipose & $\begin{array}{l}\text { Complete secretome } \\
\text { including TIMPs and } \\
\text { cartilage protecting factors }\end{array}$ & $\begin{array}{l}\text { TNF } \alpha \text {-stimulated primary articular chondrocytes: } \\
\text { blunted hypertrophy, reduced levels of osteocalcin and } \\
\text { collagen X and MMP13 activity }\end{array}$ & Osteoarthritis & Niada et al., 2019 \\
\hline Adipose & $\begin{array}{l}\text { Innate and IFN } \gamma \\
\text { preconditioned/complete } \\
\text { secretome including }>60 \\
\text { secreted } \\
\text { cytokines/chemokines and } \\
>240 \text { EV-miRNAs }\end{array}$ & $\begin{array}{l}\text {-Macrophages: increased anti-inflammatory phenotype } \\
\text { marker CD163 -Chondrocytes: reduced inflammation } \\
\text { marker VCAM1 }\end{array}$ & Joint disease & Ragni et al., 2020 \\
\hline Cornea & Complete secretome & $\begin{array}{l}\text { Ex vivo porcine cornea injury model: enhanced survival } \\
\text { of corneal endothelial cells }\end{array}$ & $\begin{array}{l}\text { Corneal endothelial } \\
\text { cell injury }\end{array}$ & $\begin{array}{l}\text { Rouhbakhshzaeri } \\
\text { et al., } 2019\end{array}$ \\
\hline Adipose & $\begin{array}{l}\text { Concentrated secretome } \\
\text { including GDNF and FGF2 }\end{array}$ & $\begin{array}{l}\text { Rat model of bilateral abdominal cryptorchidism: } \\
\text { restored seminiferous tubules, increased GATA4 } \\
\text { expression }\end{array}$ & $\begin{array}{l}\text { Non-obstructive } \\
\text { spermatogenesis } \\
\text { disorders }\end{array}$ & $\begin{array}{l}\text { Sagaradze et al., } \\
2019\end{array}$ \\
\hline Cornea & EXO & $\begin{array}{l}\text {-Cultured corneal epithelial cells: increased migration } \\
\text {-Murine epithelial debridement wounds: increased } \\
\text { wound healing }\end{array}$ & $\begin{array}{l}\text { Ocular surface } \\
\text { injuries }\end{array}$ & $\begin{array}{l}\text { Samaeekia et al., } \\
2018\end{array}$ \\
\hline
\end{tabular}


TABLE 1 | Continued

\begin{tabular}{|c|c|c|c|c|}
\hline MSC source & Secretome components & Targets: effects & Therapeutic use & References \\
\hline $\begin{array}{l}\text { Bone marrow, } \\
\text { adipose }\end{array}$ & Complete secretome & $\begin{array}{l}\text { Hypoxic primary rat alveolar epithelial cells: increased } \\
\text { viability, reduced secretion of inflammatory mediators, } \\
\text { enhanced IL-10 production, increased active MMPs }\end{array}$ & $\begin{array}{l}\text { Pulmonary } \\
\text { syndromes }\end{array}$ & Shologu et al., 2018 \\
\hline $\begin{array}{l}\text { Wharton's jelly, bone } \\
\text { marrow }\end{array}$ & EXO & $\begin{array}{l}\text { Mouse model of bronchopulmonary dysplasia: } \\
\text { ameliorated alveolar simplification, fibrosis and } \\
\text { pulmonary vascular remodeling due to hyperoxia }\end{array}$ & Pulmonary disease & Willis et al., 2018 \\
\hline
\end{tabular}

BPD, bronchopulmonary dysplasia; EV, extracellular vesicle; EXO, exosomes; FGF2, fibroblast growth factor 2; GATA4: GDF6, growth differentiation factor 6; HUVEC, human umbilical vein endothelial cells; IFN $\gamma$, interferon $\gamma ;$ IL, interleukin; IP-10, interferon $\gamma$-induced protein 10; MCP-1, monocyte chemoattractant protein-1; MMPs, matrix metalloproteases; PBMC, peripheral blood mononuclear cells; PGs, prostaglandins; PGE2, prostaglandin E2; TIMPs, tissue inhibitors of MMPs; TGF, transforming

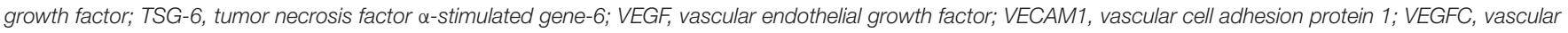
endothelial growth factor $C$.

TABLE 2 | Rodent MSC secretome components, targets, effects, and potential therapeutic uses.

\begin{tabular}{|c|c|c|c|c|c|}
\hline Rodents & MSC source & $\begin{array}{l}\text { Secretome } \\
\text { components }\end{array}$ & Targets: effects & Therapeutic use & References \\
\hline \multirow[t]{2}{*}{ Mouse } & Bone marrow & MV & $\begin{array}{l}\text { LPS stimulated microglia: prevented production of } \\
\text { pro-inflammatory molecules and upregulation of } \\
\text { proteins associated with activation, decreased } \\
\text { phosphorylation of MAPK in activation pathway }\end{array}$ & $\begin{array}{l}\text { Neuroinflammatory } \\
\text { disease }\end{array}$ & $\begin{array}{l}\text { Jaimes et al., } \\
2017\end{array}$ \\
\hline & Bone marrow & IGFBP7 & $\begin{array}{l}\text { Mouse experimental colitis model: ameliorated the } \\
\text { clinical and histological severity of inflammation, } \\
\text { restored gastrointestinal mucosal tissues }\end{array}$ & Crohn's disease & $\begin{array}{l}\text { Liao et al., } \\
2016\end{array}$ \\
\hline \multirow[t]{4}{*}{ Rat } & Bone marrow & EXO-rich secretome & $\begin{array}{l}\text {-Injured liver cells in culture: reduced cytotoxicity, } \\
\text { improved cell recovery } \\
\text {-In vivo rat liver failure models: improved liver } \\
\text { regeneration }\end{array}$ & Injured liver disease & $\begin{array}{l}\text { Damania et al., } \\
2018\end{array}$ \\
\hline & Bone marrow & $\begin{array}{l}\text { Complete secreted } \\
\text { factors including Wnt4 }\end{array}$ & $\begin{array}{l}\text { Injured islet microvascular endothelial cells: prevented } \\
\text { apoptosis, inhibited eNOS and VCAM-1 elevation, } \\
\text { increased } \beta \text {-catenin }\end{array}$ & Diabetes & $\begin{array}{l}\text { Wang et al., } \\
2017\end{array}$ \\
\hline & Bone marrow & EXO & $\begin{array}{l}\text { In vivo rat stroke model: improved functional recovery, } \\
\text { enhanced neurite remodeling, neurogenesis, and } \\
\text { angiogenesis }\end{array}$ & Stroke & Xin et al., 2013 \\
\hline & Bone marrow & $\begin{array}{l}\text { EXO including } \\
\text { argonaute } 2\end{array}$ & Primary cortical neurons: promoted axonal growth & $\begin{array}{l}\text { Traumatic brain } \\
\text { injury }\end{array}$ & $\begin{array}{l}\text { Zhang et al., } \\
2017\end{array}$ \\
\hline
\end{tabular}

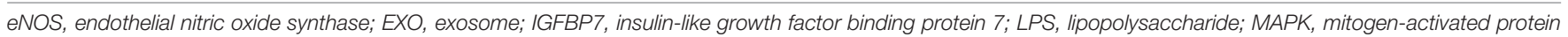
kinase; MV, microvesicles; VCAM-1, vascular cell adhesion protein 1.

the goal of determining the potential of these cells as therapies for a variety of diseases, many of which also affect humans (De Schauwer et al., 2013; Calloni et al., 2014; Devireddy et al., 2017; Sultana et al., 2018; Dias et al., 2019; Hill et al., 2019). In addition, case studies and clinical trials of MSCs isolated from companion animals have provided in vivo data further supporting the efficacy of MSC-based therapies (Caniglia et al., 2012; Carvalho et al., 2013; Renzi et al., 2013; Arzi et al., 2016; Hoffman and Dow, 2016; Geburek et al., 2017; Quimby and Borjesson, 2018). This section provides an overview of data from studies specifically designed to look at the effects of secreted factors of MSC isolated from veterinary species for diseases that are relevant to human medicine.

Veterinary species as physiologically relevant translational models for human diseases have several advantages over rodent models. When working with veterinary species MSC, results from in vitro experiments can be easily tested in the same species in vivo. In addition, most veterinary species (i) are made up of individuals with genetic variation that reflects the diversity found in human populations, (ii) have larger body sizes and longer lifespans compared to rodents, and (iii) are often exposed to the same environmental insults as humans, causing them to be susceptible to similar naturally occurring diseases, such as musculoskeletal disorders, immune-modulatory diseases, respiratory diseases, and certain cancers. As such, they serve as valuable "real world" models (Hoffman and Dow, 2016).

Small companion animals, most often dogs and cats, are domesticated animals whose physical, emotional, behavioral and social needs are met by close daily relationships with humans. Human bonds to companion animals create a demand for new and optimal pet therapies, including state-of-the-art cellbased therapies. Consequently, the growing interest in MSCbased therapies has resulted in MSCs from dogs and cats to be isolated, characterized, and studied in both the laboratory setting and clinical trials (Hoffman and Dow, 2016). Generally, the dog is considered an excellent model for human disease. In addition to sharing similar environments with humans, dogs naturally develop diseases that resemble pathologic conditions 


\section{Priming}

\section{Genetic engineering}

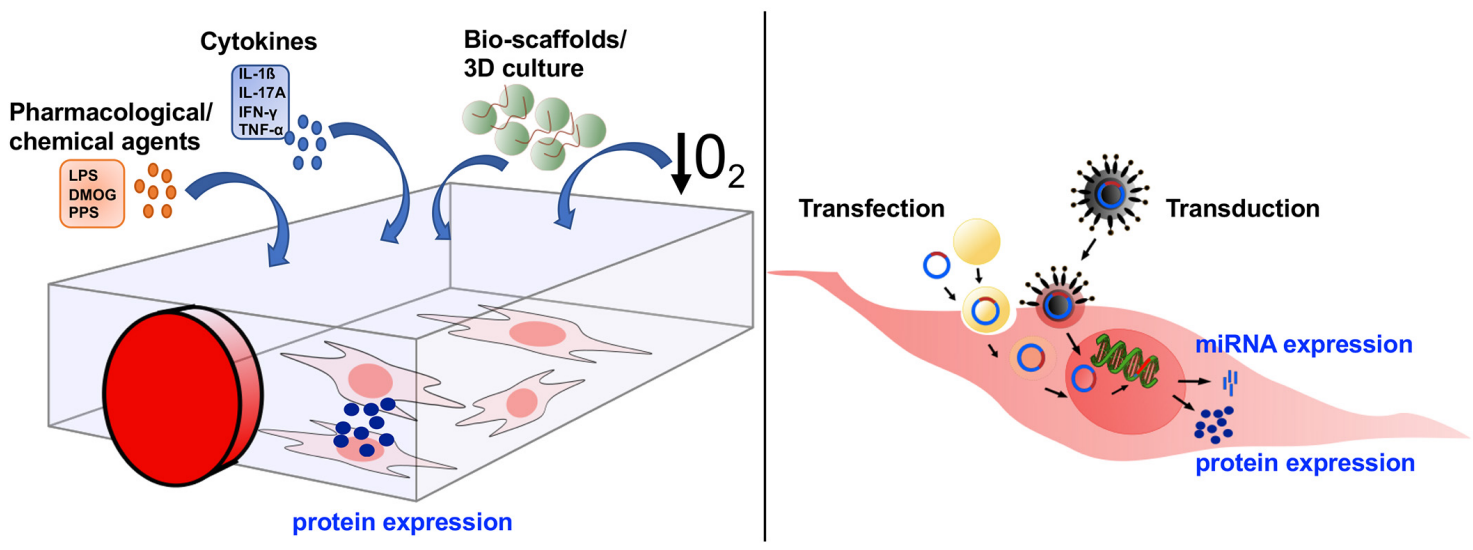

FIGURE 2 | Altering the mesenchymal stromal cell (MSC) secretome through in vitro manipulation. In order to increase the secretion of desired molecules, such as proteins or miRNA, MSCs are manipulated in culture through either priming or genetic engineering. The four main approaches of priming are (i) addition of pharmacological/chemical agents, (ii) treatment with cytokines, (iii) culture in 3D cultures/bio-scaffolds, and (iv) culture under induced hypoxic conditions. Genetic engineering is used to express/overexpress specific proteins or miRNA by a targeted RNA or DNA transfer into the MSCs via transduction, transfer by virus or viral vector, or transfection, transfer through various biological/chemical/physical approaches. DMOG, dimethyloxalylglycine; LPS, lipopolysaccharides; PPS, pentosan polysulfate; IL, interleukin; IFN, interferon; TNF, tumor necrosis factor; 3D, 3-dimensional; $\mathrm{O}_{2}$, oxygen.

of humans (Hoffman and Dow, 2016). In this regard, MSCbased therapies have been widely investigated in diseases in dogs, including osteoarthritis (OA), spinal cord injury, bone regeneration, pulmonary and cardiac disorders, cancer, intervertebral disk degeneration, atopic dermatitis, inflammatory bowel disease (IBD), non-ischemic cardiac disease, Alzheimer's disease, amyotrophic lateral sclerosis, and epilepsy (Hoffman and Dow, 2016). Cats have proven to be good models for immune-mediated diseases such as IBD as well as non-ischemic cardiac disease, and chronic kidney disease (Hoffman and Dow, 2016) (Figure 3).

Mesenchymal stromal cells have been isolated and characterized from large animals including cows, pigs, sheep, goats, and horses (Calloni et al., 2014). Of these, the majority of MSC studies have been carried out with MSCs isolated from horses, driven by the high demand of horse owners for innovative regenerative therapies, primarily geared toward the treatment of musculoskeletal injuries. Horses are well-characterized as models for specific human diseases, most notably orthopedic injuries such as OA (McCoy, 2015), but also skin wounds (Harman et al., 2019), and respiratory diseases (Klier et al., 2019), all of which have the potential to be managed by treatment with MSC secreted factors (De Schauwer et al., 2013) (Figure 3). Pigs have long been considered valuable preclinical models for a variety of human therapies, as exemplified by the use of pig organs that are quite similar to those of humans in terms of size, morphology, and function (Roth and Tuggle, 2015). Assessing stem cell-based therapeutics in pig models for skin wounds, acute liver failure, neurodegenerative disorders, general wound healing and tissue repair, diabetes mellitus, and influenza A infections, have all been proposed, and are mainly performed to fine-tune preclinical testing (Sullivan et al., 2001; Rajao and Vincent, 2015; Seaton et al., 2015; Bharti et al., 2016) (Figure 3). Moreover, there is evidence that pig MSCs can function cross-species in vivo (Li et al., 2014). Lastly, Sheep and goats are primarily used to model human OA (McCoy, 2015), and sheep also serve as models for human respiratory diseases (Meeusen et al., 2009). The sheep model has also been used to examine the therapeutic effects of EVs derived from human BM-MSCs in a preclinical model of hypoxic-ischemic brain injury in preterm neonates (Ophelders et al., 2016). In this study, ovine fetuses were subjected to global hypoxia-ischemia followed by in utero intravenous treatment with EVs. As compared to controls, brain function in fetuses treated with EVs exhibited improved brain function as determined by total number and duration of seizures and preserved baroreceptor reflex sensitivity. Although cerebral inflammation remained unaffected by this treatment, the authors proposed that MSC EVs might be a novel approach to reduce neurological consequences of hypoxic-ischemic injury of the fetal brain in humans (Ophelders et al., 2016).

It is important to point out that many MSC secreted factors are similar across species, making studies on the MSC secretome from animals relevant to human medicine. For example, immunomodulatory molecules, growth factors, antitumoral, and anti-microbial molecules, have all been documented to be secreted by MSCs isolated from humans, laboratory rodents, and veterinary species (Harman et al., 2017b; Vizoso et al., 2017; Cassano et al., 2018; Mancuso et al., 2019; Villatoro et al., 2019). Although a quantitative analysis of MSC secreted factors across species has not been carried out to our knowledge, such studies could further strengthen the translational aspect of MSC secretome studies in animals.

\section{Naïve Small Companion Animal MSCs}

The primary source of MSC isolated from dogs and studied for therapeutic use is adipose tissue (AT). The secretome of 
TABLE 3 | Manipulation of human MSCs to optimize the therapeutic effects of the MSC secretome.

\begin{tabular}{|c|c|c|c|c|}
\hline $\begin{array}{l}\text { Modification } \\
\text { (MSC source) }\end{array}$ & Manipulation & Outcome & Therapeutic use & References \\
\hline \multicolumn{5}{|l|}{ Priming } \\
\hline $\begin{array}{l}\text { Protein profile in } \\
\text { EXO (BMMSC) }\end{array}$ & $\begin{array}{l}\text { Retinal cell CM } \\
(\mathrm{TNF}-\alpha)\end{array}$ & $\begin{array}{l}\text { MSC CM and EXO had neuro-protective effects on retinal ganglion } \\
\text { cells, increased PEDF and VEGF-A in primed EXO }\end{array}$ & Optic nerve injury & Mead et al., 2020 \\
\hline $\begin{array}{l}\text { Immune- } \\
\text { modulatory } \\
\text { properties (Gingival } \\
\text { MSC) }\end{array}$ & $\mathrm{IL}-1 \beta$ & $\begin{array}{l}\text { Overexpression of TGF- } \beta \text { and MMP pathway agonists (MMP-1, } \\
\text { MMP-9), Primed MSC CM promoted cell migration, epidermal-dermal } \\
\text { junction formation, inflammation reduction in vitro and improved } \\
\text { epidermal engraftment in vivo (mice) }\end{array}$ & Wound healing & Magne et al., 2020 \\
\hline $\begin{array}{l}\text { Protein profile in } \\
\text { EXO (BMMSC) }\end{array}$ & Hypoxia & $\begin{array}{l}\text { Exosomes from primed MSC are enriched with specific } \\
\text { subclassifications of proteins, including secretory and ECM associated } \\
\text { proteins, EXO enhances secretion of growth factors of neuroblast-like } \\
\text { cells }\end{array}$ & $\begin{array}{l}\text { CNS related } \\
\text { diseases }\end{array}$ & Yuan et al., 2019 \\
\hline $\begin{array}{l}\text { Immune- } \\
\text { modulatory } \\
\text { properties } \\
\text { (UCMSC) }\end{array}$ & 3D culture & $\begin{array}{l}\text { CM had increased anti-inflammatory profile (IL-10, LIF) and trophic } \\
\text { factors (PDGF-BB, FGF-2, I-309, GM-CSF, increased therapeutic effect } \\
\text { in vivo (rats) }\end{array}$ & $\begin{array}{l}\text { Rheumatoid } \\
\text { arthritis }\end{array}$ & $\begin{array}{l}\text { Miranda et al., } \\
2019\end{array}$ \\
\hline $\begin{array}{l}\text { Senescence and } \\
\text { immune- } \\
\text { modulatory } \\
\text { properties } \\
\text { (BMMSC) }\end{array}$ & Substance P & $\begin{array}{l}\text { Increased secretion of PDGF-BB in primed MSC. Primed MSC CM } \\
\text { increased viability of retinal pigmented epithelium }\end{array}$ & $\begin{array}{l}\text { Age related } \\
\text { macular } \\
\text { degeneration }\end{array}$ & Jung et al., 2019 \\
\hline $\begin{array}{l}\text { Metabolic } \\
\text { pathways (BMMSC) }\end{array}$ & INF- $\gamma / \mathrm{TNF}-\alpha$ & $\begin{array}{l}\text { Primed MSC show increased glycolysis and fatty acid oxidation, } \\
\text { glycolysis is linked to MSC-mediated T cell suppression through the } \\
\text { JAK/STAT1/IDO axis by posttranslational modification (glycosylation) of } \\
\text { STAT1 }\end{array}$ & $\begin{array}{l}\text { General MSC } \\
\text { therapy: immune- } \\
\text { modulatory } \\
\text { properties }\end{array}$ & Jitschin et al., 2019 \\
\hline $\begin{array}{l}\text { Induction of } \\
\text { quiescent state } \\
\text { (BMMSC) }\end{array}$ & Hypoxia, SF-media & $\begin{array}{l}\text { Increased survival, adaptive response mechanism after transplantation, } \\
\text { primed MSC maintained their stemness by reaching a quiescent state. }\end{array}$ & $\begin{array}{l}\text { General MSC } \\
\text { therapy }\end{array}$ & Ferro et al., 2019 \\
\hline $\begin{array}{l}\text { Senescence and } \\
\text { immune- } \\
\text { modulatory } \\
\text { properties } \\
\text { (BMMSC) }\end{array}$ & $\begin{array}{l}\text { 3D culture in } \\
\text { FBS-containing } \\
\text { medium and } \\
\text { xeno-free medium }\end{array}$ & $\begin{array}{l}\text { MSC in 3D culture contained their immune-suppressive profile over } \\
\text { multiple passages. Upregulation of COX-2, TNF alpha induced protein } \\
6 \text {, SCT-1. Secretion of PGE } 2 \text {, TSG-6, STC-1 }\end{array}$ & $\begin{array}{l}\text { General MSC } \\
\text { therapy: immune- } \\
\text { modulatory } \\
\text { properties }\end{array}$ & $\begin{array}{l}\text { Bartosh and } \\
\text { Ylostalo, } 2019\end{array}$ \\
\hline \multicolumn{5}{|c|}{ Genetic modification: miRNA overexpression } \\
\hline $\begin{array}{l}\text { miRNA-26a-5p } \\
\text { (BMMSC) }\end{array}$ & Lentivirus & $\begin{array}{l}\text { Alleviation of damages on synovial fibroblasts by targeting PTGS2 } \\
\text { in vitro and retardation of damage in OA in vivo (rats) }\end{array}$ & Osteoarthritis & Jin et al., 2020 \\
\hline $\begin{array}{l}\text { miRNA-181a } \\
\text { (UCMSC) }\end{array}$ & Lentivirus & $\begin{array}{l}\text { Reduced inflammatory response and promoted Treg polarization in vitro } \\
\text { and an in vivo (mice) ischemic damage model }\end{array}$ & $\begin{array}{l}\text { Myocardial } \\
\text { infarction }\end{array}$ & Wei et al., 2019 \\
\hline $\begin{array}{l}\text { miRNA-122 } \\
\text { (ADMSC) }\end{array}$ & Lipofection & $\begin{array}{l}\text { Reduced collagen, inhibition of pro-inflammatory cytokines, reduction of } \\
\text { liver enzymes, elevated expression of antifibrotic proteins in vitro } \\
\text { (human HSC) and in vivo (mice) }\end{array}$ & Liver fibrosis & $\begin{array}{l}\text { Kim K.H. et al., } \\
2019\end{array}$ \\
\hline $\begin{array}{l}\text { miRNA-126 } \\
\text { (UCMSC) }\end{array}$ & Lipofection & $\begin{array}{l}\text { Alleviated effects of hypoglycemia induced inflammation in vivo (rats), } \\
\text { suppressing of HMGB-1 signaling pathway and inflammation in vitro } \\
\text { (human retina cells) }\end{array}$ & $\begin{array}{l}\text { Retinal } \\
\text { inflammation in } \\
\text { diabetes }\end{array}$ & Zhang et al., 2019 \\
\hline \multicolumn{5}{|c|}{ Genetic modification: protein overexpression via transfection } \\
\hline VEGF (BMMSC) & Microporation & Improved angiogenic potential in vitro & $\begin{array}{l}\text { Peripheral artery } \\
\text { disease }\end{array}$ & Serra et al., 2019 \\
\hline $\begin{array}{l}\text { CXCR4 (BMMSC, } \\
\text { ADMSC) }\end{array}$ & $\begin{array}{l}\text { Microporation in } \\
\text { combination with } \\
\text { minicircle transfection }\end{array}$ & Increased homing in a skin wound mouse model & $\begin{array}{l}\text { General MSC } \\
\text { therapy: homing }\end{array}$ & Mun et al., 2016 \\
\hline \multicolumn{5}{|c|}{ Genetic modification: Transduction of viral immune evasion proteins } \\
\hline $\begin{array}{l}\text { Herpesviral } \\
\text { immunoevasion } \\
\text { protein US11 } \\
\text { (BMMSC) }\end{array}$ & Lentivirus & $\begin{array}{l}\text { Downregulation of } \mathrm{MHCl} \text { proteins, increased persistence of MSC in } \\
\text { immune-competent mice with depleted } \mathrm{NK}\end{array}$ & $\begin{array}{l}\text { General MSC } \\
\text { therapy/increase of } \\
\text { immune } \\
\text { evasiveness }\end{array}$ & $\begin{array}{l}\text { de la Garza-Rodea } \\
\text { et al., } 2011\end{array}$ \\
\hline $\begin{array}{l}\text { Cytomegaloviral } \\
\text { immunoevasion } \\
\text { proteins US6/US11 } \\
\text { (not specified) }\end{array}$ & Retrovirus & $\begin{array}{l}\text { Downregulation of } \mathrm{HLA}-\mathrm{I} \text {, protection against NK in vitro, increased liver } \\
\text { engraftment in pre-immune fetal sheep }\end{array}$ & $\begin{array}{l}\text { General MSC } \\
\text { therapy/increase of } \\
\text { immune } \\
\text { evasiveness }\end{array}$ & Soland et al., 2012 \\
\hline
\end{tabular}


TABLE 3 | Continued

\begin{tabular}{|c|c|c|c|c|}
\hline $\begin{array}{l}\text { Modification } \\
\text { (MSC source) }\end{array}$ & Manipulation & Outcome & Therapeutic use & References \\
\hline \multicolumn{5}{|c|}{ Genetic modification: Gene-directed enzyme/prodrug therapy } \\
\hline HSVtk (BMMSC) & Retrovirus & $\begin{array}{l}\text { Clinical trial, administration of transduced MSC in combination with prodrug } \\
\text { ganciclovir: } 4 \text { of } 6 \text { patients reached stable disease, safe and feasible }\end{array}$ & $\begin{array}{l}\text { Gastrointestinal } \\
\text { adenocarcinoma }\end{array}$ & $\begin{array}{l}\text { von Einem et al., } \\
2017\end{array}$ \\
\hline HSVtk (BMMSC) & Retrovirus & $\begin{array}{l}\text { Clinical trial, administration of transduced MSC in combination with prodrug } \\
\text { ganciclovir: } 50 \% \text { of patients reached stable disease, safe and feasible }\end{array}$ & $\begin{array}{l}\text { Gastrointestinal } \\
\text { adenocarcinoma }\end{array}$ & $\begin{array}{l}\text { von Einem et al., } \\
2019\end{array}$ \\
\hline $\begin{array}{l}\text { CD::UPRT or } \\
\text { HSVtk (ADMSC) }\end{array}$ & & $\begin{array}{l}\text { Systemic administration of human CD::UPRT-MSC or HSVtk-MSC in combination } \\
\text { with 5-FC and ganciclovir inhibited growth of lung metastases in mice }\end{array}$ & $\begin{array}{l}\text { Gastrointestinal } \\
\text { adenocarcinoma }\end{array}$ & $\begin{array}{l}\text { Matuskova et al., } \\
2015\end{array}$ \\
\hline
\end{tabular}

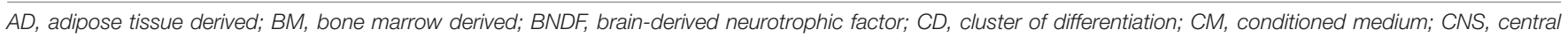

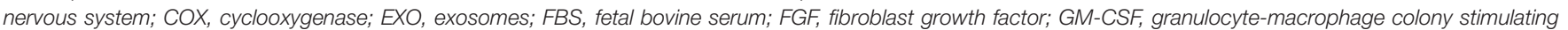

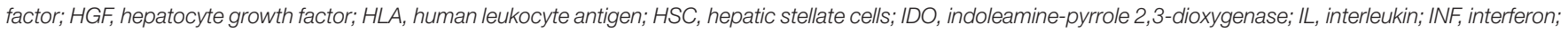

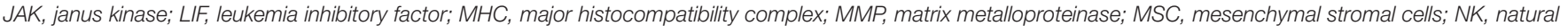

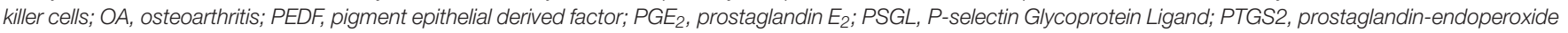

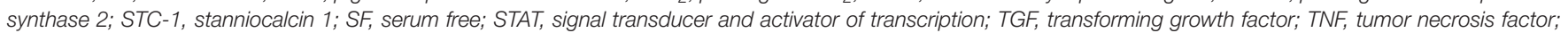

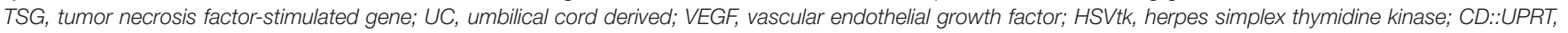
fusion yeast cytosine deaminase::uracil phosphoribosyltransferase, 5-FC: 5-fluorocytosine.

AT-derived MSCs from dogs has the potential to influence neurologic diseases, immune-related diseases and cancer. In vitro experiments designed to examine the paracrine action of dog AT-derived MSCs on neuronal and endothelial cells showed that treating a neuronal cell line with conditioned medium (CM) from MSC cultures significantly increased cell proliferation, neurite outgrowth and expression of the neuronal marker $\beta$ III-tubulin (Al Delfi et al., 2016). Exposure of an endothelial cell line to this dog MSC CM increased cell proliferation and migration, as well as inducing tubule formation in a soluble basement membrane matrix, suggesting that the MSC secretome contains proangiogenic factors (Al Delfi et al., 2016). The authors concluded that these data support the hypothesis that transplanted MSC can promote increased neural function in dogs with CNS damage, due to paracrine activity on nerves and blood vessels (Al Delfi et al., 2016). Of note is that the neuronal and endothelial cell lines used in this study for the experiments were of human origin. The fact that dog-derived secretome components stimulated human cells suggests common inter-species mechanisms that endorse the use of veterinary models for human medicine. Another in vitro study aimed to compare immunomodulatory properties of dog AT- and bone marrow (BM)-derived MSCs. In these experiments, proliferation of stimulated peripheral blood mononuclear cells (PBMCs) from dogs co-cultured with ATor BM-derived MSCs was inhibited when compared to non-cocultured controls (Russell et al., 2016). The authors concluded that the in vitro immunomodulatory effects were mediated by MSC secreted factors and proposed future in vivo experiments to determine the efficacy of MSCs to modulate the immune system during inflammation-based conditions in dogs (Russell et al., 2016). Experiments testing the effects of dog AT-derived MSC CM on tumor cell growth showed that the MSC CM enhanced proliferation and invasion of a dog hepatocellular carcinoma cell (HCC) line in vitro and altered mRNA expression levels of genes related to tumor progression in HCC cells (Teshima et al., 2018). The results of this study seemingly contradicted multiple earlier studies on the effects of human MSC CM on human HCC cell lines, where inhibition of proliferation and invasion were observed (Li et al., 2010; Zhao et al., 2012). This indicates that more research is needed in both species to determine if and how the MSC secretome influences cancer cell growth and tumor progression (Teshima et al., 2018).

The secretome of AT-derived MSC from cats has been studied as well, particularly in the context of immune modulation. IBD is an autoimmune disease common in both cats and humans. In vitro experiments showed that prostaglandin $\mathrm{E}_{2}\left(\mathrm{PGE}_{2}\right)$ secreted by cat AT-MSC induced elevation of Forkhead box P3 (FOXP3) mRNA and altered the expression of inflammatory cytokines in concanavalin A (Con A)-stimulated PBMCs (An et al., 2018). Complementary studies in a Dextran sulfate sodium -treated mouse model of colitis demonstrated that intraperitoneal infusion of cat AT-MSCs reduced the clinical and histopathologic severity of colitis, and FOXP3 $+\mathrm{T}$ cells were significantly increased in the inflamed colon of MSCtreated mice as compared to controls (An et al., 2018). The authors concluded that $\mathrm{PGE}_{2}$ secreted by cat AT-MSC likely reduced inflammation by increasing FOXP3 + regulatory T cells in the mouse model and proposed that MSC-derived $\mathrm{PGE}_{2}$ may improve IBD and other immune-mediated inflammatory diseases in cats (An et al., 2018). Cat AT-MSC secreted factors have been shown to decrease proliferation of Con A-stimulated PBMCs, suggesting an additional anti-inflammatory mechanism (Parys et al., 2017). Inhibition of cat AT-MSC secreted PGE $_{2}$ by indomethacin or NS-398 was shown to reduce the antiproliferative effects of AT-MSC CM on cat PBMCs, confirming that $\mathrm{PGE}_{2}$ is involved in the immunomodulatory effects exerted by the MSC secretome (Chae et al., 2017; Taechangam et al., 2019). One of these studies also showed that cat AT-MSC secreted factors alter cytokine expression in cat PBMCs as well as a murine macrophage cell line, providing more evidence that inter-species studies of the MSC secretome can provide data that is relevant to human medicine (Chae et al., 2017). A more detailed comparison of the cat and human AT-MSC secretome using ELISAs and enzyme activity assays, revealed that AT-MSC from both species secrete $\mathrm{PGE}_{2}$, indoleamine 2,3 dioxygenase, transforming growth factor beta (TGF $\beta$ ) and 
TABLE 4 | Manipulation of laboratory rodent MSCs to optimize the therapeutic effects of the MSC secretome.

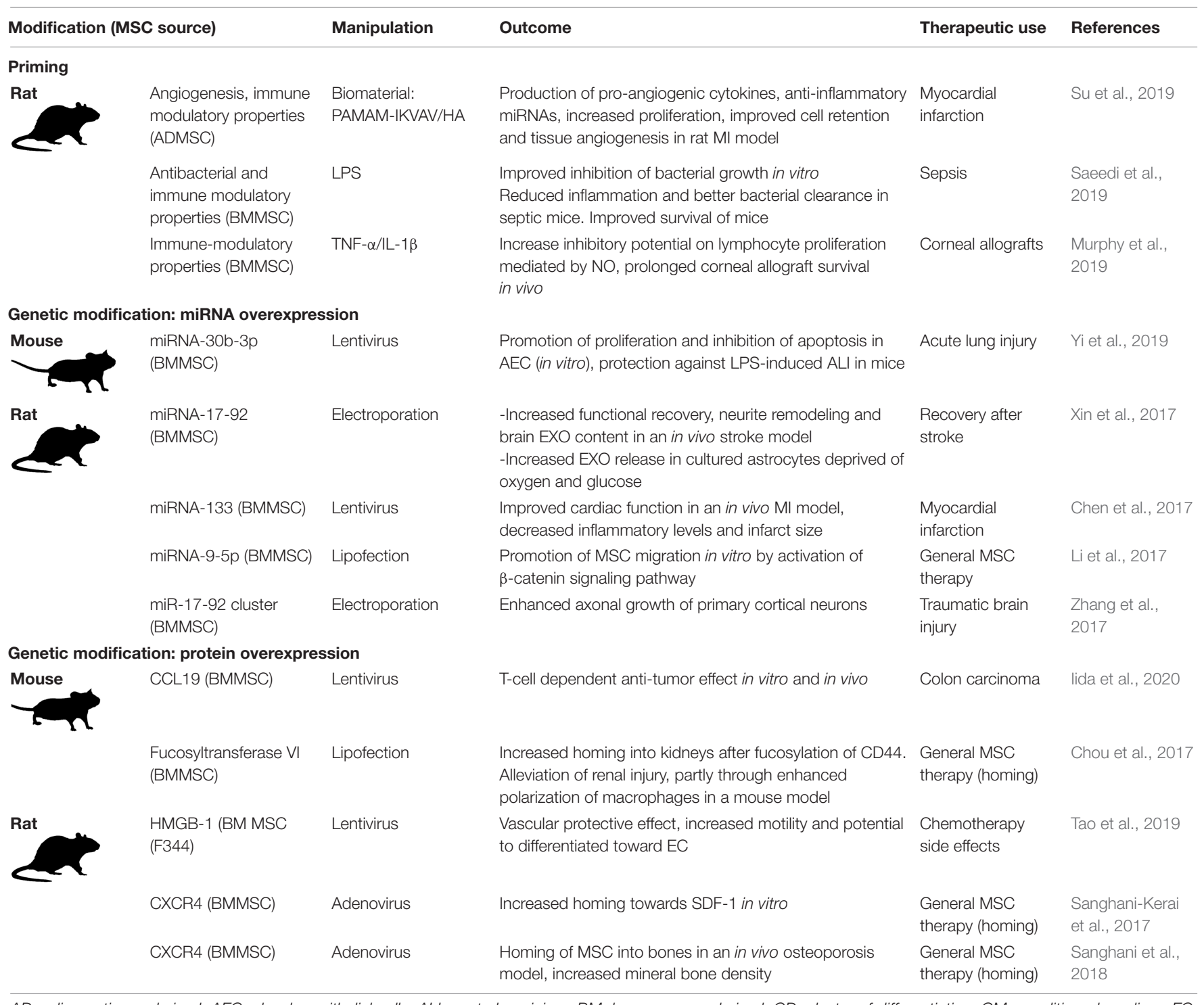

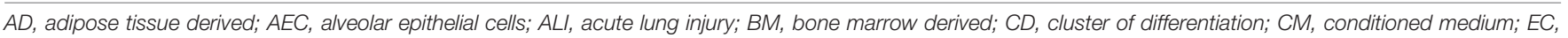

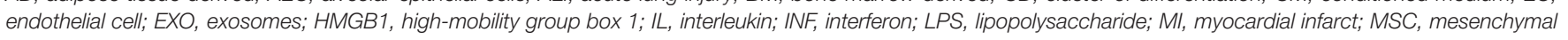

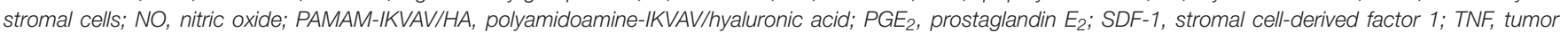
necrosis factor; UC, umbilical cord derived.

interleukin (IL)- 6, and that secretion of these proteins was increased when MSCs were co-cultured with stimulated PBMCs (Clark et al., 2017). Clinical trials using cats with naturally occurring inflammatory and immune-mediated diseases could, therefore, be used as surrogate models for human clinical trials (Clark et al., 2017). Supernatants from cat BM- and AT-derived MSC cultures have also been shown to modulate immune cells by inhibiting the reactive oxygen species (ROS) production by cat neutrophils in vitro. Although the authors of this study did not attempt to identify specific factors in the supernatants that were responsible for exerting this effect, it was determined to be dose dependent, with ROS production decreasing when neutrophils were cultured in medium made up of increasing percentages of MSC supernatants (Mumaw et al., 2015). Moreover, cat MSCs from both sources displayed similar effects on neutrophil ROS production, and the authors further concluded that supernatants from cat BM- and AT-derived MSC cultures could be clinically useful in diseases in which neutrophilic inflammation plays a significant role (Mumaw et al., 2015).

A concise overview of these studies of dog and cat MSC secreted factors is presented in Table 5 .

\section{Naïve Large Animal MSCs}

Horse MSC isolation and therapeutic application for orthopedic injuries was first described in 2003 (Smith et al., 2003). The technique was declared "rational and feasible," but conclusions could not be made based on a single case report without appropriate controls. More comprehensive studies, carried out 


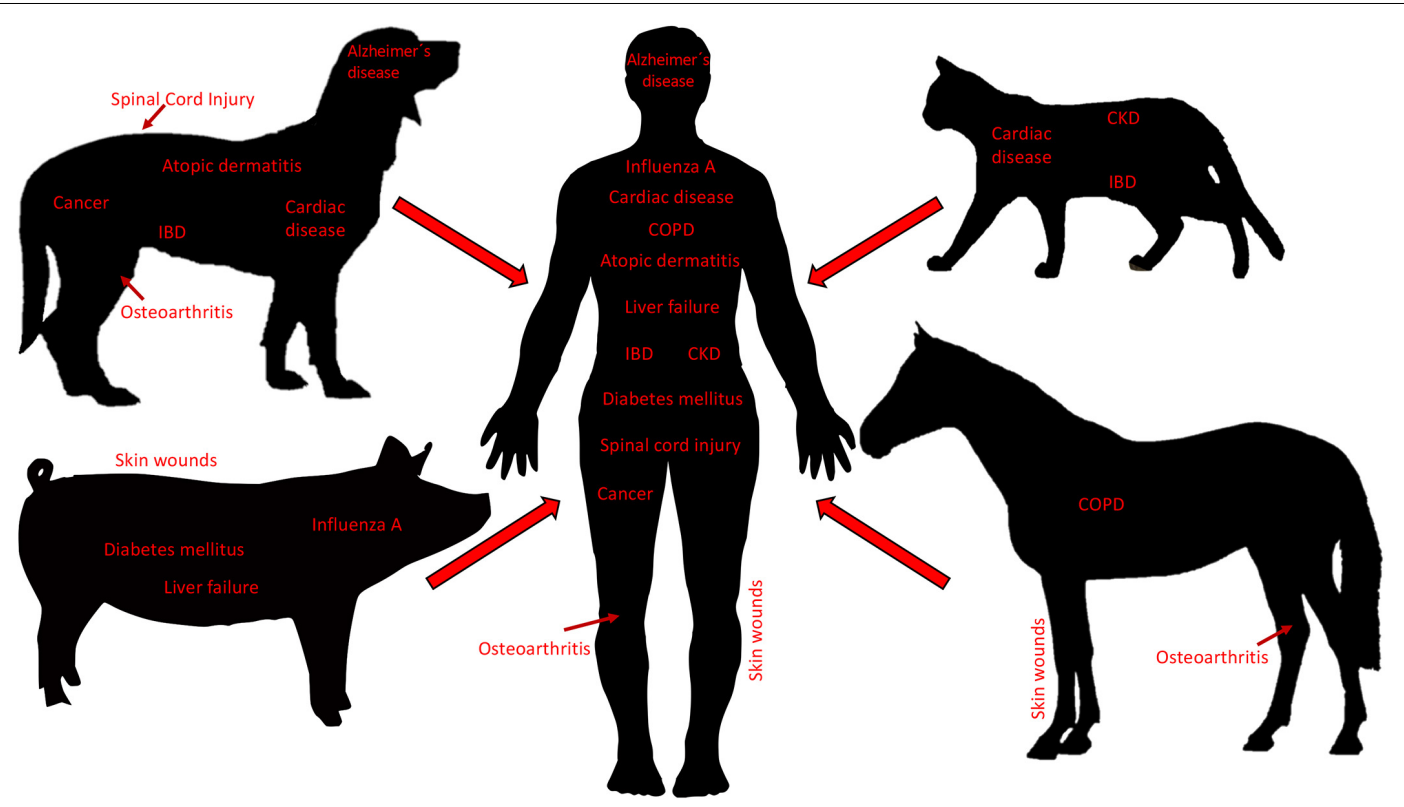

FIGURE 3 | Diseases in veterinary species as translational models for human disease. Small companion animals (i.e., dogs and cats), as well as large animals (i.e., pigs and horses), develop pathologies that are similar to diseases in humans and thus, are used as translational animal models for neurological, cardiac, pulmonary, musculoskeletal, nephrological, gastroenterological, dermatological, infectious, and cancerous, diseases. Body sizes are not to scale. IBD, inflammatory bowel disease; CKD, chronic kidney disease; COPD, chronic obstructive pulmonary disease.

TABLE 5 | Small companion animal MSC secretome components, targets, effects, and potential therapeutic uses.

\begin{tabular}{|c|c|c|c|c|c|}
\hline Animal & MSC source & $\begin{array}{l}\text { Secretome } \\
\text { components }\end{array}$ & Targets: effects & Therapeutic use & References \\
\hline \multirow[t]{2}{*}{ Dog } & Adipose & Complete secretome & $\begin{array}{l}\text {-Human neuronal cells: increased proliferation, neural } \\
\text { outgrowth, immunopositivity for neural marker } \beta \text { III-tubulin } \\
\text {-Human endothelial cells: increased migration, } \\
\text { proliferation, tube formation }\end{array}$ & Neurological disorders & $\begin{array}{l}\text { Al Delfi et al., } \\
2016\end{array}$ \\
\hline & $\begin{array}{l}\text { Adipose, } \\
\text { bone marrow }\end{array}$ & Complete secretome & Canine lymphocytes: suppressed proliferation & Immune-related diseases & $\begin{array}{l}\text { Russell et al., } \\
2016\end{array}$ \\
\hline \multirow[t]{5}{*}{ Cat } & Adipose & PGE2 & $\begin{array}{l}\text {-Feline regulatory T cells: increased FOXP3 gene } \\
\text { expression, altered cytokine gene expression } \\
\text {-Mouse colitis model: reduced severity of disease }\end{array}$ & $\begin{array}{l}\text { Inflammatory bowel disease } \\
\text { treatment }\end{array}$ & An et al., 2018 \\
\hline & Adipose & Complete secretome & Feline PBMC: reduced proliferation & Inflammatory disorders & Parys et al., 2017 \\
\hline & Adipose & $\begin{array}{l}\text { Complete } \\
\text { secretome/PGE2 }\end{array}$ & Feline T Iymphocyte: reduced proliferation & $\begin{array}{l}\mathrm{CD} 4+\text { and } \mathrm{CD} 8+\text { mediated } \\
\text { alloreactive diseases }\end{array}$ & $\begin{array}{l}\text { Taechangam } \\
\text { et al., } 2019\end{array}$ \\
\hline & Adipose & Complete secretome & Feline PBMCs: reduced activated T-cell proliferation & Regenerative medicine & Clark et al., 2017 \\
\hline & Bone marrow & Complete secretome & Feline neutrophils: reduced production of ROS & $\begin{array}{l}\text { Diseases dependent on } \\
\text { neutrophilic inflammation }\end{array}$ & $\begin{array}{l}\text { Mumaw et al., } \\
2015\end{array}$ \\
\hline
\end{tabular}

IFN- $\gamma$, interferon- $\gamma$; IL-6: IL-10, interleukin-10; FOXP3, forkhead box P3; MMP2, matrix-metallopeptidase 2; PBMCs, peripheral blood mononuclear cells; PGE2, prostaglandin E2; ROS, reactive oxygen species; TNF $\alpha$, tumor necrosis factor $\alpha$.

in the past 15 years, have established that autologous MSC therapy is not detrimental to horses and the use of MSCs to treat orthopedic injuries has been accepted as a valuable therapeutic approach (Bogers, 2018; Al Naem et al., 2020). There are still many unanswered questions about the immunogenicity of allogenic horse MSC. Although allogenic MSC hold promise as 
treatments for numerous diseases of horses, such as endotoxemia, IBD, asthma and recurrent uveitis, more data are needed before allogenic cells can be used clinically (Berglund et al., 2017b; MacDonald and Barrett, 2020).

To the best of our knowledge, neither the cell-free complete secretome nor specific secretome components of horse MSCs have been delivered to horses in vivo. However, we and others have worked extensively in vitro, and to a lesser extent in vivo in rodent models, to characterize the horse MSC secretome and its effects on target cells (Table 6). Specifically, our research focuses on the horse peripheral blood (PB) derived-MSC secretome in the context of cutaneous skin wounds, which is not only of significant importance in equine medicine but can also greatly benefit human medicine by taking advantage of horse cutaneous wounds as translational models for the evaluation of human MSC-based therapies (Harman et al., 2019). For example, we found that in vitro (i) endothelin 1 (ET1), IL-8, platelet derived growth factor-AA (PDGF-AA), and insulin-like growth factor binding protein 2 (IGFBP2), present in the horse PBMSC secretome promotes angiogenesis and (ii) plasminogen activator inhibitor 1 (PAI-1) and tenascin-C (TNC) secreted by PB-MSC increases fibroblast migration (Bussche and Van de Walle, 2014; Harman et al., 2018). Importantly, we confirmed the active roles of PAI- 1 and TNC in fibroblast migration by repeating the experiments with secretome in which these factors were silenced using RNA interference and followed up by testing the contribution of these MSC-secreted proteins to wound healing in vivo in a mouse full-thickness skin injury model. Although this work confirmed the bioactive roles of these factors, our results showed that these two proteins did not account for the full wound healing effect of the complete secretome (Harman et al., 2018). Additional studies from our group identified anti-microbial peptides in the horse PB-MSC secretome that inhibit the growth of contaminating bacteria commonly found in skin wounds, as well as cysteine proteases that destabilize bacterial biofilms in vitro (Harman et al., 2017b; Marx et al., 2020). Moreover, we confirmed that the chemokine C-X-C motif ligand 6 (CXCL6) secreted by horse PB-MSC acts as a chemoattractant for neutrophils in vitro (Harman et al., 2020). Collectively, our research has identified specific factors secreted by PB-MSC that promote various aspects of skin wound healing, supporting the notion that the complete MSC secretome provides therapeutic benefits by targeting various aspects of specific disease processes.

Early studies of MSCs from cows, pigs, sheep, and goats, primarily focused on MSC characterization based on phenotypic marker expression and the potential to differentiate into adipocytes, chondrocytes, and osteocytes in vitro (Bosch et al., 2006; Cardoso et al., 2012; Heidari et al., 2013; MohamadFauzi et al., 2015). More recently, global proteomic analysis of the secretome of cow endometrial MSCs identified 302 unique proteins, including those with anti-inflammatory or antibacterial properties and proteins related to tissue remodeling. After stimulating these MSCs with lipopolysaccharide (LPS), an increased 397 proteins were detected in the secretome, particularly those proteins involved in immunomodulation and tissue repair, leading the authors to conclude that these cow
MSCs could be useful to treat reproductive diseases of cattle (de Moraes et al., 2017). Additional in vitro studies showed that the secretome from fetal cow MSC reduced the growth of $S$. aureus (Cahuascanco et al., 2019) and promoted endothelial cells to form tubules, an in vitro proxy for angiogenic potential (Jervis et al., 2019). Based on currently available data, the cow MSC secretome has been proposed as a treatment for mastitis, wound healing, nerve injuries, degenerative joint diseases and other diseases of the skeletal system, as well as diabetes mellitus (Gugjoo et al., 2019; Hill et al., 2019).

The immunomodulatory functions of soluble factors secreted by pig MSC have been studied in vitro, demonstrating that $\mathrm{PGE}_{2}$ suppresses the functionality of dendritic cells and T-cells (Khatri et al., 2015). Applying the secretome of pig corneal MSCs to injured corneal endothelial cells ex vivo, significantly reduced endothelial cell loss when compared to control conditions (Rouhbakhshzaeri et al., 2019). Moreover, it was found that LPS-damaged pig enteric ganglia were protected upon treatment with the secretome of pig MSC using an in vitro model of IBD (Dothel et al., 2019). The activity of pig MSC-derived EVs has also been studied in depth. For example, a study comparing the miRNA, RNA, and protein, expression profiles in the complete secretome of pig AT-derived-MSC to those profiles found in the EV fraction from these cells, showed that 4 miRNAs and 255 mRNAs were specifically enriched in EVs (Eirin et al., 2017). Another study evaluated the anti-influenza activity of EVs isolated from pig BM-MSC in lung epithelial cells in vitro and in a pig model of influenza infection in vivo (Khatri et al., 2018). The in vitro experiments showed that EVs were incorporated into epithelial cells, inhibited the hemagglutination activity and replication of influenza virus, and reduced virusinduced apoptosis of lung epithelial cells. In vivo, treatment with EVs significantly reduced influenza virus shedding in the nasal epithelium, viral replication in the lungs, and virusinduced proinflammatory cytokines in the lungs of infected pigs (Khatri et al., 2018).

Sheep MSCs have primarily been studied in terms of their potential to contribute to joint and cartilage repair (Music et al., 2018). For example, the administration of chondrogenically predifferentiated MSCs, embedded in hydrogels at the site of induced osteochondral injury in the medial femoral condyle of sheep, resulted in significantly improved histological scores at 6 months and 1-year post-administration when compared to controls (Zscharnack et al., 2010; Marquass et al., 2011). Since it is known that implanted MSC do not persist long term, these encouraging findings could be a result of factors secreted by the MSCs. To the best of our knowledge, however, specific effects of the sheep MSC secretome on osteochondral defects has not been examined in vitro nor in vivo.

\section{Manipulated Small Companion Animal MSCs (Dog)}

Many strategies to optimize therapies with dog MSCs focus on enhancing the differentiation potential of these cells, primarily into chondrocytes and osteocytes. A main goal of establishing a stable chondrocyte phenotype from dog 
TABLE 6 | Horse MSC secretome components, targets, effects, and potential therapeutic uses.

\begin{tabular}{|c|c|c|c|c|}
\hline MSC Source & Secretome components & Targets: effects & Therapeutic use & References \\
\hline Peripheral blood & $\begin{array}{l}\text { ET1, IL-8, PDGF-AA, } \\
\text { IGFBP2 }\end{array}$ & Endothelial cells: increased angiogenesis & Tissue regeneration & $\begin{array}{l}\text { Bussche and Van de } \\
\text { Walle, } 2014\end{array}$ \\
\hline Bone marrow & Glycosaminoglycan & BM-MSC: decreased PDL & Maintaining stemness & Sasao et al., 2015 \\
\hline Peripheral blood & Complete secretome & $\begin{array}{l}\text { Dermal fibroblasts: increased migration, altered gene } \\
\text { expression }\end{array}$ & Cutaneous wound healing & Bussche et al., 2015 \\
\hline Amnion & Complete secretome, EV & $\begin{array}{l}\text { LPS stimulated and unstimulated alveolar macrophages: } \\
\text { cytokine secretion }\end{array}$ & Inflammatory lung diseases & Zucca et al., 2016 \\
\hline Peripheral blood & Antimicrobial peptides & E. coli, S. aureus: inhibition of growth, biofilm formation & Cutaneous wound healing & Harman et al., 2017b \\
\hline Peripheral blood & Complete secretome & $\begin{array}{l}\text { Dermal fibroblasts, healthy and dysregulated: alterations in } \\
\text { morphology, proliferation, gene expression, contractile } \\
\text { capacity and susceptibility to senescence }\end{array}$ & Fibroproliferative disorders & Harman et al., 2017a \\
\hline Bone marrow & Complete secretome & Corneal stromal cells: increased migration & Corneal wound healing & Sherman et al., 2017 \\
\hline Bone marrow & Galectin-1/3 & BMMSC: increased motility & Osteoarthritis & Reesink et al., 2017 \\
\hline Peripheral blood & PAl-1, tenascin-C & $\begin{array}{l}\text { Dermal fibroblasts, mouse skin wounds: increased } \\
\text { migration, wound closure }\end{array}$ & Cutaneous wound healing & Harman et al., 2018 \\
\hline Amnion & MicroRNAs & Secretome not tested with targets in a model system & Regenerative medicine & $\begin{array}{l}\text { Lange-Consiglio } \\
\text { et al., } 2018\end{array}$ \\
\hline Adipose & EV derived small RNAs & Secretome not tested with targets in a model system & Regenerative medicine & $\begin{array}{l}\text { Capomaccio et al., } \\
2019\end{array}$ \\
\hline Bone marrow & $\begin{array}{l}\text { Inflammatory, angiogenic } \\
\text { proteins }\end{array}$ & Secretome not tested with targets in a model system & Osteoarthritis & $\begin{array}{l}\text { Bundgaard et al., } \\
2020\end{array}$ \\
\hline Peripheral blood & $\begin{array}{l}\text { Complete secretome, } \\
\text { cysteine proteases }\end{array}$ & $\begin{array}{l}\text { P. aeruginosa, S. aureus, S. epidermidis: inhibition and } \\
\text { destabilization of biofilms }\end{array}$ & Bacterial skin infections & Marx et al., 2020 \\
\hline Peripheral blood & CXCL6 & Neutrophils: chemotaxis & Tissue repair & Harman et al., 2020 \\
\hline
\end{tabular}

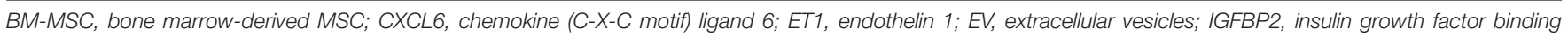

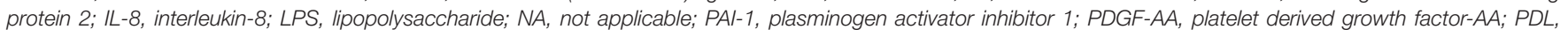
population doubling level.

MSCs is to increase their deposition of articular cartilage proteins, so that these cells can become an effective treatment option for chronic OA. For example, it was found that exposing canine AT-MSCs to hypoxic conditions resulted in increased proliferation, a downregulation of genes associated with senescence like histone acetylase 1 (HDAC 1) and DNAcytosine-5-methyltransferase (DNMT1), and an upregulation of genes that are associated with the potential to differentiate into chondrocytes like collagen type II alpha 1 (COL2A1) (Lee et al., 2016). Another study showed that culturing dog AT-MSCs with dimethyloxalylglycine (DMOG), which mimics hypoxic conditions by stabilizing hypoxia-inducible factor1alpha (HIF1a), led to an increased expression of the signal protein vascular endothelial growth factor (VEGF), important in angiogenesis and thus, beneficial in diseases with ischemic conditions. However, high concentrations of DMOG did inhibit MSC proliferation (Kim S.M. et al., 2019). Importantly, it was found that the serum used in MSC cultures can alter the immunomodulatory properties of dog AT-MSC, since MSCs cultured in serum-free medium secreted lower levels of $\mathrm{PGE}_{2}$ and were less efficient in inhibiting interferon (INF)$\gamma$ secretion by activated T-cells (Clark et al., 2016). Culturing dog BM-MSC with pentonsan polysulfate (PPS) in a micromass culture system, successfully enhanced chondrogenesis and proteoglycan deposition. However, repeating these experiments in an alginate culture system did not result in a chondrocyte phenotype, pointing out the importance of the culture conditions for obtaining the desired MSC phenotype (Bwalya et al., 2017). Increased chondrogenesis and glycosaminoglycan (GAG) deposition was also observed when dog BM-derived periadipocytes (BMPAGs) were stimulated with fibroblast growth factor 2 (FGF2) in serum-free medium. BMPAGs are MSCs derived from cells adhering to adipocytes in the BM, and the authors proposed that this special site of isolation explained a lower donor variability in their results when compared to earlier studies that used BM-MSC (Endo et al., 2019). To increase clinical effectiveness of dog BM-MSC, Steffen et al. (2019) attached BM-MSC on a collagen microcarrier scaffold, in the presence or absence of immobilized TGF- $ß 1$ and found an increased chondrogenic phenotype in vitro. Following up on this finding in a clinically study with canine patients suffering from intervertebral disc (IVD) degeneration, however, did not find any improvement that could be associated with the MSC treatment (Steffen et al., 2019).

While the majority of dog MSC studies focus on increasing differentiation potential, as outlined above, some studies did investigate the effects on paracrine signaling by priming MSCs. Dog umbilical cord blood (UC)-derived MSCs were primed with $\beta$-tricalcium phosphate, a combination previously found to produce promising osteogenic material (Jang et al., 2008), and then evaluated in an ectopic implantation model. On day 1 after implantation, tissue collected from UC-MSC- $\beta$-calcium implants showed an increase of $I L-1, I L-6$, and VEGF RNA expression as well as increased protein levels of IL- 6 and VEGF when compared 
to controls, and this cytokine release was proposed to mediate the enhanced bone formation observed (Byeon et al., 2010). In addition to the potential of dog MSCs to modulate chondroand/or osteogenesis, their benefits in immune-mediated diseases, such as inflammatory bowel syndrome that affects both dogs and humans, have also been explored (Hoffman and Dow, 2016). In this context, it was investigated how gastrointestinal microbes interact with dog AT-MSCs in order to understand if an altered gastrointestinal microbiome affects MSC therapy outcome in IBD (Kol et al., 2014). Based on the knowledge that (i) MSCs are known to express pattern recognition receptors (PRRs) and (ii) activation of MSCs through PRR ligands alters the MSC secretome (DelaRosa and Lombardo, 2010), it was explored whether co-culture of dog AT-MSCs with gastrointestinal commensal (Lactobacillus acidophilus) and pathogenic (Salmonella typhimurium) bacteria affected their phenotype. Although no increased cell death or upregulation of surface proteins major histocompatibility complex (MHC)-II, cluster of differentiation (CD)80/CD86, or CD1 was detected, the canine MSCs (i) did express higher RNA levels of COX2, IL6 and IL8, (ii) secreted more PGE 2 , IL-6 and IL-8, and (iii) showed a higher ability to inhibit mitogen induced T-cell proliferation (Kol et al., 2014). The authors concluded that microbe-MSC interaction alters MSC functionality, and thus, that this needs to be taken into consideration when MSCs are explored as therapy in diseases associated with bacterial colonization (Kol et al., 2014). Another study evaluated the value of PRR expression for priming of AT-MSC in both mouse and dog models (Johnson et al., 2017). First, they showed that activation of mouse MSCs with poly I:C through the PRR Toll-like receptor 3 (TLR3) resulted in an altered secretome profile including increased secretion of the monocyte chemoattractant CC-chemokine ligand 2 (CCL2). CM from these primed MSCs (i) led to increased murine monocyte recruitment in an in vitro migration assay and (ii) stimulated neutrophils to increase their phagocytosis of bacteria in vitro. A follow up in vivo experiment in mice showed increased homing of activated MSCs to infected wounds (Johnson et al., 2017). When the effects of intravenously injected allogenic poly I:C-activated dog AT-MSCs were evaluated in canine patients suffering from chronic multi-drug resistant bacterial infections, the authors found that the MSC infusions were well tolerated, with no notable side effects, and that the conditions in all enrolled dogs either improved of resolved by the end of observation period. This prompted the authors to conclude that their pre-clinical study provides strong rationale to establish primed MSCs as a therapy for chronic bacterial infections (Johnson et al., 2017).

Due to their low immunogenicity and their homing ability, dog MSCs have also been explored as "trojan horses." For example, the canine adenovirus ICOCAV17 has anti-tumor effects, but this virus is readily neutralized by the host immune system. To allow ICOCAV17 to reach the tumor site, dog AT-MSCs were infected with this virus and used to treat 27 dogs suffering from various cancerous diseases (Cejalvo et al., 2018). Of those, $74 \%$ benefited from the therapy and $14 \%$ even showed total remission. Interestingly, the study found increased immune cell infiltrations into the tumors after treatment, and this immune-related response to the infected MSCs was deemed to play an important role in the observed clinical benefits (Cejalvo et al., 2018). Similar studies in humans, using the human oncolytic adenovirus ICOVIR-5 to infect human MSCs, however, were less promising (Garcia-Castro et al., 2010; Melen et al., 2016; Ruano et al., 2020). When the cellular responses of human and dog MSCs to ICOVIR-5 and ICOCAV17, respectively, were compared, it was found that ICOVIR-5, but not ICOCAV17, intrinsically induces a strong phosphorylation of AKT and c-JUN (Rodríguez-Milla et al., 2020). Activation of the AKT pathway is associated with (i) virus latency by suppressing apoptosis of the host cell, (ii) host cell survival in chronic viral infections, and (iii) short-term cellular survival in acute viral infections depending on the virus and type of infection (Cooray, 2004). The authors concluded that an impaired cellular signaling in dog MSCs after ICOCAV17 infection, due to the lack of AKT activation, might lead to a more restricted host immune response after injection of dogs with these virusinfected MSCs, which could explain the better clinical outcome (Rodríguez-Milla et al., 2020). This study is a nice example of how comparative studies between species can lead to a better understanding of the underlying mechanisms responsible for certain clinical outcomes.

In addition to infecting dog MSCs with oncolytic viruses, several studies have been conducted to evaluate the use of genetically modified MSCs to treat cancer in dogs. For example, the effects of INF- $\beta$ overexpression in dog AT-MSCs against canine melanoma has been studied intensively (Seo et al., 2011; Ahn et al., 2013; Han et al., 2015b). Transfected MSCs performed slightly better than naïve cells in vitro, with their secretome showing improved pro-apoptotic and cell growth inhibitory effects on canine melanoma cells (Han et al., 2015b). In vivo, INF- $\beta$ overexpressing dog AT-MSCs did migrate to the tumor site after subcutaneous injection in a mouse model, and these mice showed increased survival time when the MSC treatment was combined with the chemotherapeutic cisplatin (Seo et al., 2011). These findings were corroborated a few years later when INF- $\beta$ overexpressing $\operatorname{dog}$ AT-MSCs were used in vitro and in a xenograft in vivo mouse model of canine melanoma. Importantly, this study found that melanoma cell proliferation was inhibited using an indirect co-culture system, indicating that the anti-tumor effects rely on factors in the MSC secretome (Ahn et al., 2013). Genetically modified dog AT-MSCs overexpressing cytotoxic T-lymphocyte antigen 4 (CTLA4), with the goal to increase immune suppressive properties, have also been explored. Specifically, T-lymphocyte infiltration into thyroid glands was found to be decreased, as well as thyroglobulin antibodies in the serum, upon treatment with CTLA4-AT-MSCs in an induced thyroiditis model in beagles (Choi et al., 2015). These cells have also been used as treatment in a case study of a dog with therapy-resistant pemphigus foliaceus, an immune-mediated disease that leads to severe skin lesion and reduces quality of life immensely (Olivry, 2006). In this case study, the dog received 21 injections with CTLA4-AT-MSCs over a period of 20 months. The lesions improved and the patient reached a stable state of disease 
that could be controlled with low-dose prednisolone for a year (Han et al., 2015a). Lastly, dog AT-MSCs transduced with a tyrosine mutant adeno-associated virus 2 vector to overexpress stromal-derived factor-1 (SDF-1), with the goal to promote MSC homing and survival, have been evaluated in dogs with dilated cardiomyopathy (Pogue et al., 2013). Although the SDF-1-ATMSCs were successfully administered via retrograde coronary venous delivery and no adverse effects were observed, the treatment failed to improve clinical outcome in the enrolled dogs (Pogue et al., 2013).

\section{Manipulated Large Animal MSCs (Horse)}

As previously mentioned, the horse is a widely used and wellaccepted model for OA. Early on, the hypothesis was that MSCs would engraft in pathological joints and differentiate into chondrocytes, and as such, mitigate joint trauma. In order to increase clinical outcome, horse BM-MSCs were primed in vitro with TGF- $\beta 1$ and insulin-like growth factor-I (IGFI), which increased the chondrogenic potential of these horse MSCs (Worster et al., 2001). However, it is now generally accepted that the observed therapeutically effects of MSCs are not due to their engraftment, but due to immunomodulation via paracrine signaling. Although it is known that the expression of immunogenic and immunomodulation-related genes and molecules in MSCs change in a proinflammatory environment, potentially activating the immunomodulatory properties of these cells, it was found that the equine synovial fluid of inflamed joints alone was not sufficient to enhance the immunoregulatory profile of horse BM-MSCs (Barrachina et al., 2016). Consequently, several studies focused on increasing the immunomodulatory properties by priming horse MSCs in vitro in culture before administration in vivo. For example, a dose-dependent stimulation of horse BM-MSCs with the cytokines tumor necrosis factor $\alpha(\mathrm{TNF}-\alpha)$ and INF- $\gamma$ led to an upregulation of immunoregulatory genes without affecting viability and differentiation potential (Barrachina et al., 2017a, 2018). Although INF- $\gamma$ priming increased the chondroprotective effect of horse BM-MSCs, the expression of MHC-I and MHC-II was also upregulated, implicating an increased immunogenicity (Barrachina et al., 2017b; Hill et al., 2017; Cassano et al., 2018). In line with these in vitro results, an in vivo study in an equine OA model showed only slightly improved clinical signs, as well as synovial inflammatory signs, when horses were treated with allogeneic naïve or TNF- $\alpha / \mathrm{INF}-\gamma$ primed horse BM-MSCs. Moreover, injection of these primed MSCs led to a transient local inflammation reaction after the second injection, most likely due to the production of allo-antibodies that recognized these primed $\mathrm{MHC}$-mismatched MSCs with high expression levels of MHC-class I and II molecules (Berglund and Schnabel, 2017; Barrachina et al., 2018, 2020). More recently, priming horse BM-MSCs with TGF- $\beta 2$ has been identified as a promising strategy to inhibit INF $\gamma$-induced MHC I and II surface expression in vitro, thus, potentially improving MSC survival and therapeutic efficacy (Berglund et al., 2017a).

Genetically modified horse MSCs have also been explored and one of the first in vivo studies used horse BM-MSCs that were successfully transduced with an adenoviral vector to overexpress IGF-I in a model of equine tendinitis (Schnabel et al., 2009). Tendon histological scores improved after treatments with both naïve MSCs and IGF-I-MSCs, leading to the conclusion that horse MSCs might be beneficial for the treatment of tendinitis, but without a superior effect from transfected MSC (Schnabel et al., 2009). In equine OA, the nuclear factor $\kappa \mathrm{B}$ (NFкB) signaling pathway, which can be activated by the cytokines IL- $B 1$ and TNF- $\alpha$ that are naturally present in inflamed joints, has been determined to be a key signaling pathway contributing to disease pathology. IL1- $\beta$ and TNF- $\alpha$ not only activate NFKB but become in turn also upregulated by this activated pathway, thus creating a positive autoregulatory loop that can amplify inflammation (Marcu et al., 2010). Equine MSCs have been engineered with the goal to interrupt this inflammatory response. For example, the usefulness of a tunable gene expression vector under the control of an NFKB-responsive enhancer/promoter that can be regulated by the pro-inflammatory cytokines IL- $1 \beta$ and TNF- $\alpha$ has been explored (Gabner et al., 2016). As proof of concept, the reporter gene luciferase was used to show that stimulation of transduced MSCs with IL- $1 \beta$ and TNF- $\alpha$ indeed led to the expression of the reporter gene in a dose dependent manner (Gabner et al., 2016). In a follow-up study, the authors then replaced the reporter gene with the gene encoding for interleukin-1 receptor antagonist (IL-1Ra) and found that its expression could be modulated by repeated cycles of induction with TNF- $\alpha$. Importantly, they could demonstrate that IL-1Ra present in the secretome of these transduced MSCs effectively blocked OA onset in an in vitro model using horse chondrocytes (Gabner et al., 2018). Based on these findings, the authors suggested that transduced MSCs that are administered to inflamed joints and express tunable IL-1Ra in response to the pro-inflammatory cytokines present in these inflamed joints, are a promising strategy to promote joint homeostasis.

\section{DISCUSSION}

Understanding the biologically active factors that make up the human MSC secretome and manipulating these cells to consistently secrete factors of therapeutic importance, will improve MSC secretome-based therapies. Emerging single-cell technologies will undoubtedly help decipher the heterogeneity of MSCs and allow for the selection of MSC subsets that secrete therapeutically desirable factors. To date, single-cell transcriptomic analyses of human MSCs resulted in varied outcomes. For example, umbilical cord-derived MSCs were found to exhibit limited heterogeneity, whereas Wharton's jelly derived MSCs were found to be functionally heterogeneous in terms of proliferative capacity and wound healing potential (Huang et al., 2019; Sun et al., 2020). Single-cell RNA sequencing of mouse BM-derived MSCs revealed multiple profiles as well, some associated with distinct differentiation potential (Freeman et al., 2015). Our group used single-cell transcriptomics to analyze donor-matched equine MSCs isolated from three different tissue sources and we found inter- and intra-source genetic heterogeneity that resulted in functional 
heterogeneity in immune function and cell motility (Harman et al., 2020). The emerging technology of high-resolution precision proteomics is currently only being used to evaluate cancer cellular heterogeneity (Waas and Kislinger, 2020), but will certainly be transferrable to MSCs, where this technique can provide additional insights into the heterogeneity of MSC populations to allow for the purification of MSC subpopulations with high secretory potential.

In addition to identifying the molecules produced by MSCs that have the functional characteristics to lead to desired clinical outcomes, there are further aspects to consider when moving MSC secretome therapy from bench to bedside. Here, we discuss two of those aspects by asking the following questions. First, is the use of a rich compilation of bioactive MSC secreted factors required for maximal therapeutic benefit, and second, what options are available for delivery of the MSC secretome to target tissues?

\section{Advantages and Disadvantages of Using a Compilation of Bioactive MSC Secreted Factors}

The use of a compilation of bioactive factors secreted by MSCs that have either been primed to overproduce therapeutically valuable molecules or genetically engineered to produce and secrete these molecules, may be more effective than solely administering the individual factors of interest. As discussed earlier, studies from our group indicated that although specific proteins in the horse PB-MSC secretome contribute to cellular functions associated with wound healing, they did not account for the full effectiveness of the complete secretome as observed in both in vitro and in vivo wound healing assays (Harman et al., 2018). In general, most studies documenting the efficacy of the MSC secretome to promote tissue repair and/or modulate the immune system do not indicate precisely which factors are responsible for the beneficial effects. The most obvious reason for using a compilation of bioactive MSC secreted factors over discrete individual factors, is the fact that the secretome is comprised of a myriad of bioactive nucleic acids, proteins, and lipids, that all have the potential to interact with target cells and tissues on different levels (Harrell et al., 2019). Consequently, the use of a compilation of MSC secreted bioactive factors provides numerous molecules that may function together in networks in order to obtain the maximal effect. This is illustrated by previously discussed data from our own group. We have identified proteins with regenerative properties and proteins with antimicrobial properties in the secretome of horse PBMSCs (Bussche and Van de Walle, 2014; Bussche et al., 2015; Harman et al., 2017a,b, 2018, 2020, Marx et al., 2020). Using these identified factors individually could be therapeutically useful to promote wound healing or to fight bacterial infections. However, using the secretome as a whole may capitalize on a treatment that reduces bacteria in infected wounds, while simultaneously restoring the tissue damage caused by acute injury and pathogens.

This benefit is also evident by the recognition that MSCderived EVs, widely studied as a form of cell-free MSC therapy, are made up of a compilation of factors, including nucleic acids, particularly small regulatory RNAs, proteins and lipids. Secreted factors contained in EVs are more stable than secreted factors that are free in solution and they are more likely to be taken up by target cells via interactions of surface ligands/receptors, adhesion of membrane integrins, or endocytosis of the EVs (Sarko and McKinney, 2017; Eleuteri and Fierabracci, 2019). EVs from many cell types are known to be involved in cellcell signaling, as well as tissue regeneration, and it has been demonstrated that EVs are comprised of RNAs, proteins, and lipids, that are distinct from those secreted freely from their cells of origin (Barreca et al., 2020). For example, comparative analyses of miRNAs detected in EXOs and the EXO-cells-oforigin have clearly demonstrated that miRNA composition of EXOs and the cells they were secreted from differ widely, suggesting active packaging of miRNAs into this class of EV (Zhang et al., 2015). Among miRNAs known to be upregulated in EVs, are those involved in the regulation of angiogenesis (Liang et al., 2016; Salinas-Vera et al., 2018). Moreover, EVs transport various cytosolic proteins involved in cell proliferation and migration, such as FGF2 that lacks the exocytosis signals needed to be secreted through the endoplasmic reticulum-Golgi pathway (Candela et al., 2010). In general, EVs are enriched in sphingosine-1-phosphate, a signaling lipid that in itself induces cell proliferation and migration (Xiang et al., 2018).

In addition to the important therapeutic benefit of administering a compilation of bioactive factors secreted by MSCs, there are certainly some disadvantages to this approach. Most notably, and as discussed throughout this review, is the inconsistency in the effectiveness of secretome therapy due to variability of the MSC secretome based on individual donor, tissue source of origin, culture method, and duration of MSCs in culture. As reviewed, these inconsistencies can be addressed by priming and/or genetically modifying MSCs to generate a more consistent secretome. Other strategies to produce a more consistent MSC secretome include (i) consideration of the age, sex and health status of MSC donors, (ii) purposefully using MSC from specific tissue sources, (iii) carefully documenting MSC culture conditions and (iv) limiting the length of time MSCs are maintained in culture (Sagaradze et al., 2018). Indeed, experts in the field of MSC secretome-based drug development state that generating a consistent MSC secreted product with testable potency is the first step needed to move this cell-free therapy from laboratory testing to clinical use (Sagaradze et al., 2018).

\section{Delivery of the MSC Secretome}

As described in this review, the secretomes of MSCs isolated from various species and/or different tissue sources contain bioactive factors that have the potential to be used as cell-free therapies. In order to be effective, MSC secretome components must be delivered to target tissues and interact with target cells. On the one hand, administering the MSC secretome therapeutically avoids some of the hurdles associated with MSC cell-based therapies such as the risk of triggering the innate or adaptive immune responses and the possibility of donor cell engraftment and tumorigenicity (Caplan et al., 2019). On the other hand, MSC 
secretome-based therapies presents challenges such as retaining secreted factors at the appropriate sites and protecting them from degradation. Select strategies for the delivery of the stem cell secretome have been recently reviewed (Daneshmandi et al., 2020), so here, we will primarily discuss additional strategies that have been described for the delivery of the secretome from other cell types that may also be appropriate for administering MSC secreted factors. Modes of secretome administration can be roughly divided into two categories: direct and associated with a delivery vehicle.

Direct administration includes the injection or application of CM from cultured MSCs at the site of injury, e.g., cutaneous wounds, as well as the injection of exosomes (EXOs) systemically into the blood stream (Daneshmandi et al., 2020). The MSC secretome may also be delivered directly by inhalation for certain diseases (Khan et al., 2017; Grinblat et al., 2018; Dane et al., 2020). For example, treatments with CM from human induced pluripotent stem cells (iPSCs) were delivered by inhalation every 5 days following unilateral pneumonectomy (PNX) in a dog model of destructive lung disease. This study revealed that repetitive inhalation of the iPSC secretome increased alveolar angiogenesis and enhanced septal remodeling associated with improved gas exchange compensation in the lungs (Dane et al., 2020). Moreover, intranasal delivery of the MSC secretome may also have neuroprotective effects, as shown in a study evaluating the efficacy of the secretome of the human amnion-derived multipotent progenitor cells, named ST266 (Grinblat et al., 2018). Specifically, five daily intranasal treatments with ST266 of mice with surgically induced optic nerve crush injuries, resulted in increased retinal ganglion cell (RGC) survival and showed a trend toward reduced RGC axon and myelin damage (Grinblat et al., 2018). In another study, intranasally administered ST266 showed potent neuroprotective and anti-inflammatory effects on the optic nerve in a mouse experimental autoimmune model of multiple sclerosis (Khan et al., 2017).

Historically, MSCs themselves have been used as "delivery vehicles" for their secretome which evolved from the practice of injecting MSCs, locally or systemically, with the goal of having them differentiate and expand at the site of injury to replace damaged tissue (Galipeau and Sensébé, 2018; Krueger et al., 2018; Martin et al., 2019). As it became clear that MSCs do not survive long after administration and that the beneficial effects they exert are due to the factors they secrete that influence recipient target cells, MSCs have served as delivery vehicles in their own right (Spees et al., 2016; Krueger et al., 2018). An active field of research is the engineering of delivery vehicles that allow for the prolonged release of therapeutic molecules at sites of injured tissue. Cells that secrete bioactive factors or bioactive factors in solution can be carried in the vehicles. Delivery vehicles include (i) synthetic polymerbased scaffolds, which increase hydrophilicity and improve cell/secretome immobilization, (ii) hydrogels that retain cells or secreted factors and allow for controlled release, and (iii) fabricated secretome-loaded microparticles that can reside in damaged tissues releasing bioactive factors for days without being rejected by the recipient immune system (Ryu et al., 2019; Daneshmandi et al., 2020). Our group conducted an in vitro proof-of-concept study aimed to determine if equine PB-MSCs survived when encapsulated in core shell hydrogel microcapsules, and if MSC secreted factors could diffuse through the capsules and affect target cells (Bussche et al., 2015). We found that MSCs survived for over 3 weeks in the capsules and that CM collected from these encapsulated MSCs promoted dermal fibroblast migration and changes in fibroblast gene expression, suggesting that MSCs encapsulated in this way may be appropriate for therapy (Bussche et al., 2015). Commercially available, implantable cell devices may also serve as delivery vehicles for the MSC secretome. In a rat model of myocardial infarction, animals were subjected to permanent ligation of the left anterior descending coronary artery and then treated with a subcutaneous implantation of human cardiac stem cells enclosed in a TheraCyte device (Kompa et al., 2020). This device retained the cells and protected them from the recipient immune system, while allowing cellular secreted factors to exit. Treated rats showed preserved cardiac function, reduced fibrotic scar tissue, interstitial fibrosis and cardiomyocyte hypertrophy, as well as increased myocardial vascular density when compared to controls (Kompa et al., 2020).

Taken together, both the direct and indirect methods shown to be effective at delivering the secretomes of other cells types are highly likely translatable to the MSC secretome as well. Such methodologies can then be tested and refined in translation animal models, as discussed above, to further improve and optimize MSC secretome therapy in humans.

\section{CONCLUSION}

To optimize the human MSC secretome as a therapy, MSCsecreted factors must be better characterized and MSC cultures should be consistent in terms of reliably producing adequate quantities of biologically active molecules of interest. Methods to minimize variation between MSC cultures and to promote enhanced or selective secretion of specific bioactive molecules include priming and genetic engineering of MSCs. Once secretome components are optimized for maximum therapeutic benefits, targeted delivery methods are needed to direct them to injured tissues. Studies in veterinary species have already provided a wealth of information on which molecules are present in the MSC secretome and are therapeutically valuable, and on how to manipulate MSCs to preferentially secrete molecules of interest. Importantly, many of these studies have been carried out in vivo in these translational animal models with similar diseases as seen in humans, and they will continue to serve as valuable models to evaluate effective MSC-secreted factor delivery methods in a preclinical setting, that will not only benefit the model species, but human medicine as well.

\section{AUTHOR CONTRIBUTIONS}

$\mathrm{RH}$ and $\mathrm{CM}$ performed the bibliographic research, drafted the manuscript, and created the figures and tables. GV supervised the process, revised the manuscript, and finalized the manuscript. 
All the authors contributed to the article and approved the submitted version.

\section{FUNDING}

We would like to acknowledge the National Institute of Food and Agriculture, U.S. Department of Agriculture, who support our MSC secretome studies, both as a Hatch Grant No. 1017027 and an Agriculture \& Food Research Initiative Competitive Grant No.

\section{REFERENCES}

Abbasi-Malati, Z., Roushandeh, A. M., Kuwahara, Y., and Roudkenar, M. H. (2018). Mesenchymal stem cells on horizon: a new arsenal of therapeutic agents. Stem Cell Rev. Rep. 14, 484-499. doi: 10.1007/s12015-018-9817-x

Ahn, J. O., Lee, H. W., Seo, K., Kang, S. K., Ra, J. C., and Youn, H. Y. (2013). Anti-tumor effect of adipose tissue derived-mesenchymal stem cells expressing interferon- $\beta$ and treatment with cisplatin in a xenograft mouse model for canine melanoma. PLoS One 8:e74897. doi: 10.1371/journal.pone.0074897

Al Delfi, I. R., Sheard, J. J., Wood, C. R., Vernallis, A., Innes, J. F., Myint, P., et al. (2016). Canine mesenchymal stem cells are neurotrophic and angiogenic: An in vitro assessment of their paracrine activity. Vet. J. 217, 10-17. doi: 10.1016/j. tvjl.2016.09.003

Al Naem, M., Bourebaba, L., Kucharczyk, K., Röcken, M., and Marycz, K. (2020). Therapeutic mesenchymal stromal stem cells: isolation, characterization and role in equine regenerative medicine and metabolic disorders. Stem Cell Rev. Rep. 16, 301-322. doi: 10.1007/s12015-019-09932-0

Alvarez-Erviti, L., Seow, Y., Yin, H., Betts, C., Lakhal, S., and Wood, M. J. (2011). Delivery of siRNA to the mouse brain by systemic injection of targeted exosomes. Nat. Biotechnol. 29, 341-345. doi: 10.1038/nbt.1807

An, J.-H., Song, W.-J., Li, Q., Kim, S.-M., Yang, J.-I., Ryu, M.-O., et al. (2018). Prostaglandin E2 secreted from feline adipose tissue-derived mesenchymal stem cells alleviate DSS-induced colitis by increasing regulatory $\mathrm{T}$ cells in mice. BMC Vet. Res. 14:354. doi: 10.1186/s12917-018-1684-9

Arzi, B., Mills-Ko, E., Verstraete, F. J. M., Kol, A., Walker, N. J., Badgley, M. R., et al. (2016). Therapeutic efficacy of fresh, autologous mesenchymal stem cells for severe refractory gingivostomatitis in cats: autologous MSCs for severe refractory FCGS. Stem Cells Trans. Med. 5, 75-86. doi: 10.5966/sctm.20150127

Baberg, F., Geyh, S., Waldera-Lupa, D., Stefanski, A., Zilkens, C., Haas, R., et al. (2019). Secretome analysis of human bone marrow derived mesenchymal stromal cells. Biochim. Biophys. Acta Proteins Proteomics 1867, 434-441. doi: 10.1016/j.bbapap.2019.01.013

Bari, Ferrarotti, Di Silvestre, Grisoli, Barzon, Balderacchi, et al. (2019). Adipose mesenchymal extracellular vesicles as alpha-1-antitrypsin physiological delivery systems for lung regeneration. Cells 8:965. doi: 10.3390/cells8090965

Barrachina, L., Cequier, A., Romero, A., Vitoria, A., Zaragoza, P., Vázquez, F. J., et al. (2020). Allo-antibody production after intraarticular administration of mesenchymal stem cells (MSCs) in an equine osteoarthritis model: effect of repeated administration, MSC inflammatory stimulation, and equine leukocyte antigen (ELA) compatibility. Stem Cell Res. Ther. 11:52. doi: 10.1186/s13287020-1571-8

Barrachina, L., Remacha, A. R., Romero, A., Vázquez, F. J., Albareda, J., Prades, M., et al. (2016). Effect of inflammatory environment on equine bone marrow derived mesenchymal stem cells immunogenicity and immunomodulatory properties. Vet. Immunol. Immunopathol. 171, 57-65. doi: 10.1016/j.vetimm. 2016.02.007

Barrachina, L., Remacha, A. R., Romero, A., Vázquez, F. J., Albareda, J., Prades, M., et al. (2017a). Inflammation affects the viability and plasticity of equine mesenchymal stem cells: possible implications in intra-articular treatments. J. Vet. Sci. 18, 39-49. doi: 10.4142/jvs.2017.18.1.39

Barrachina, L., Remacha, A. R., Romero, A., Vázquez, F. J., Albareda, J., Prades, M., et al. (2017b). Priming equine bone marrow-derived mesenchymal stem cells with proinflammatory cytokines: implications in
2017-05722 to GV, and as a fellowship Grant No. DE20EQ-406 from the Morris Animal Foundation to CM.

\section{ACKNOWLEDGMENTS}

We thank Katherine Churchill for locating manuscripts relevant to portions of this review and Arianna Bartlett for making the animal silhouettes. We apologize to authors whose work was not cited due to space limitations.

immunomodulation-immunogenicity balance, cell viability, and differentiation potential. Stem Cells Dev. 26, 15-24. doi: 10.1089/scd.2016.0209

Barrachina, L., Remacha, A. R., Romero, A., Vitoria, A., Albareda, J., Prades, M., et al. (2018). Assessment of effectiveness and safety of repeat administration of proinflammatory primed allogeneic mesenchymal stem cells in an equine model of chemically induced osteoarthritis. BMC Vet. Res. 14:241. doi: 10.1186/ s12917-018-1556-3

Barreca, M. M., Cancemi, P., and Geraci, F. (2020). Mesenchymal and induced pluripotent stem cells-derived extracellular vesicles: the new frontier for regenerative medicine? Cells 9:1163. doi: 10.3390/cells9051163

Bartosh, T. J., and Ylostalo, J. H. (2019). Efficacy of 3D culture priming is maintained in human mesenchymal stem cells after extensive expansion of the cells. Cells 8:1031. doi: 10.3390/cells8091031

Berglund, A. K., and Schnabel, L. V. (2017). Allogeneic major histocompatibility complex-mismatched equine bone marrow-derived mesenchymal stem cells are targeted for death by cytotoxic anti-major histocompatibility complex antibodies. Equine Vet. J. 49, 539-544. doi: 10.1111/evj.12647

Berglund, A. K., Fisher, M. B., Cameron, K. A., Poole, E. J., and Schnabel, L. V. (2017a). Transforming growth factor- $\beta 2$ downregulates major histocompatibility complex (MHC) I and MHC II surface expression on equine bone marrow-derived mesenchymal stem cells without altering other phenotypic cell surface markers. Front. Vet. Sci. 4:84. doi: 10.3389/fvets. 2017.00084

Berglund, A. K., Fortier, L. A., Antczak, D. F., and Schnabel, L. V. (2017b). Immunoprivileged no more: measuring the immunogenicity of allogeneic adult mesenchymal stem cells. Stem Cell Res. Ther. 8:288. doi: 10.1186/s13287-0170742-8

Bharti, D., Belame Shivakumar, S., Baregundi Subbarao, R., and Rho, G.-J. (2016). Research advancements in porcine derived mesenchymal stem cells. Curr. Stem Cell Res. Ther. 11, 78-93. doi: 10.2174/1574888X106661507231 45911

Bogers, S. H. (2018). Cell-based therapies for joint disease in veterinary medicine: what we have learned and what we need to know. Front. Vet. Sci. 5:70. doi: 10.3389/fvets.2018.00070

Bosch, P., Pratt, S. L., and Stice, S. L. (2006). Isolation, characterization, gene modification, and nuclear reprogramming of porcine mesenchymal stem cells1. Biol. Reprod. 74, 46-57. doi: 10.1095/biolreprod.105.045138

Bundgaard, L., Stensballe, A., Elbæk, K. J., and Berg, L. C. (2020). Mass spectrometric analysis of the in vitro secretome from equine bone marrowderived mesenchymal stromal cells to assess the effect of chondrogenic differentiation on response to interleukin-1 $\beta$ treatment. Stem Cell Res. Ther. 11:187. doi: 10.1186/s13287-020-01706-7

Bussche, L., and Van de Walle, G. R. (2014). Peripheral blood-derived mesenchymal stromal cells promote angiogenesis via paracrine stimulation of vascular endothelial growth factor secretion in the equine model: stimulation of VEGF production by PB-MSCs. Stem Cells Trans. Med. 3, 1514-1525. doi: 10.5966/sctm.2014-0138

Bussche, L., Harman, R. M., Syracuse, B. A., Plante, E. L., Lu, Y.-C., Curtis, T. M., et al. (2015). Microencapsulated equine mesenchymal stromal cells promote cutaneous wound healing in vitro. Stem Cell Res. Ther. 6:66. doi: 10.1186/ s13287-015-0037-x

Bwalya, E. C., Kim, S., Fang, J., Wijekoon, H. M. S., Hosoya, K., and Okumura, M. (2017). Effects of pentosan polysulfate and polysulfated glycosaminoglycan on chondrogenesis of canine bone marrow-derived mesenchymal stem cells in 
alginate and micromass culture. J. Vet. Med. Sci. 79, 1182-1190. doi: 10.1292/ jvms.17-0084

Byeon, Y. E., Ryu, H. H., Park, S. S., Koyama, Y., Kikuchi, M., Kim, W. H., et al. (2010). Paracrine effect of canine allogenic umbilical cord blood-derived mesenchymal stromal cells mixed with beta-tricalcium phosphate on bone regeneration in ectopic implantations. Cytotherapy 12, 626-636. doi: 10.3109/ 14653249.2010 .481665

Cahuascanco, B., Bahamonde, J., Huaman, O., Jervis, M., Cortez, J., Palomino, J., et al. (2019). Bovine fetal mesenchymal stem cells exert antiproliferative effect against mastitis causing pathogen Staphylococcus aureus. Vet. Res. 50:25. doi: 10.1186/s13567-019-0643-1

Calloni, R., Viegas, G. S., Türck, P., Bonatto, D., and Pegas Henriques, J. A. (2014). Mesenchymal stromal cells from unconventional model organisms. Cytotherapy 16,3-16. doi: 10.1016/j.jcyt.2013.07.010

Candela, M. E., Geraci, F., Turturici, G., Taverna, S., Albanese, I., and Sconzo, G. (2010). Membrane vesicles containing matrix metalloproteinase-9 and fibroblast growth factor- 2 are released into the extracellular space from mouse mesoangioblast stem cells. J. Cell Physiol. 224, 144-151. doi: 10.1002/jcp.22111

Caniglia, C. J., Schramme, M. C., and Smith, R. K. (2012). The effect of intralesional injection of bone marrow derived mesenchymal stem cells and bone marrow supernatant on collagen fibril size in a surgical model of equine superficial digital flexor tendonitis: effect of stem cells on collagen fibril size in tendon injury. Equine Vet. J. 44, 587-593. doi: 10.1111/j.2042-3306.2011.00514.x

Caplan, H., Olson, S. D., Kumar, A., George, M., Prabhakara, K. S., Wenzel, P., et al. (2019). Mesenchymal stromal cell therapeutic delivery: translational challenges to clinical application. Front. Immunol. 10:1645. doi: 10.3389/fimmu. 2019.01645

Capomaccio, S., Cappelli, K., Bazzucchi, C., Coletti, M., Gialletti, R., Moriconi, F., et al. (2019). Equine adipose-derived mesenchymal stromal cells release extracellular vesicles enclosing different subsets of small RNAs. Stem Cells Int. 2019, 1-12. doi: 10.1155/2019/4957806

Cardoso, T. C., Ferrari, H. F., Garcia, A. F., Novais, J. B., Silva-Frade, C., Ferrarezi, M. C., et al. (2012). Isolation and characterization of Wharton's jellyderived multipotent mesenchymal stromal cells obtained from bovine umbilical cord and maintained in a defined serum-free three-dimensional system. BMC Biotechnol. 12:18. doi: 10.1186/1472-6750-12-18

Carvalho, A., de, M., Badial, P. R., Álvarez, L. E. C., Yamada, A. L. M., Borges, A. S., et al. (2013). Equine tendonitis therapy using mesenchymal stem cells and platelet concentrates: a randomized controlled trial. Stem Cell Res. Ther. 4:85. doi: $10.1186 /$ scrt236

Caseiro, A. R., Santos Pedrosa, S., Ivanova, G., Vieira Branquinho, M., Almeida, A., Faria, F., et al. (2019). Mesenchymal stem/ stromal cells metabolomic and bioactive factors profiles: a comparative analysis on the umbilical cord and dental pulp derived stem/ stromal cells secretome. PLoS One 14:e0221378. doi: 10.1371/journal.pone.0221378

Cassano, J. M., Schnabel, L. V., Goodale, M. B., and Fortier, L. A. (2018). Inflammatory licensed equine MSCs are chondroprotective and exhibit enhanced immunomodulation in an inflammatory environment. Stem cell Res. Ther. 9:82. doi: 10.1186/s13287-018-0840-2

Cejalvo, T., Perisé-Barrios, A. J., Del Portillo, I., Laborda, E., Rodriguez-Milla, M. A., Cubillo, I., et al. (2018). Remission of spontaneous canine tumors after systemic cellular viroimmunotherapy. Cancer Res. 78, 4891-4901. doi: 10.1158/ 0008-5472.Can-17-3754

Chae, H.-K., Song, W.-J., Ahn, J.-O., Li, Q., Lee, B.-Y., Kweon, K., et al. (2017). Immunomodulatory effects of soluble factors secreted by feline adipose tissuederived mesenchymal stem cells. Vet. Immunol. Immunopathol. 191, 22-29. doi: 10.1016/j.vetimm.2017.07.013

Chaubey, S., Thueson, S., Ponnalagu, D., Alam, M. A., Gheorghe, C. P., Aghai, Z., et al. (2018). Early gestational mesenchymal stem cell secretome attenuates experimental bronchopulmonary dysplasia in part via exosome-associated factor TSG-6. Stem Cell Res. Ther. 9:173. doi: 10.1186/s13287-018-0903-4

Chen, X., Liang, H., Zhang, J., Zen, K., and Zhang, C. Y. (2012). Secreted microRNAs: a new form of intercellular communication. Trends Cell Biol. 22, 125-132. doi: 10.1016/j.tcb.2011.12.001

Chen, Y., Zhao, Y., Chen, W., Xie, L., Zhao, Z. A., Yang, J., et al. (2017). MicroRNA133 overexpression promotes the therapeutic efficacy of mesenchymal stem cells on acute myocardial infarction. Stem Cell Res. Ther. 8:268. doi: 10.1186/s13287017-0722-z
Choi, E. W., Lee, J. M., Lee, H. W., Yang, J., and Youn, H. Y. (2015). Therapeutic effects of CTLA4Ig gene-transduced adipose tissue-derived mesenchymal stem cell transplantation on established autoimmune thyroiditis. Cell Transplant. 24, 2221-2236. doi: 10.3727/096368914x685122

Chou, K. J., Lee, P. T., Chen, C. L., Hsu, C. Y., Huang, W. C., Huang, C. W., et al. (2017). CD44 fucosylation on mesenchymal stem cell enhances homing and macrophage polarization in ischemic kidney injury. Exper. Cell Res. 350, 91-102. doi: 10.1016/j.yexcr.2016.11.010

Clark, K. C., Fierro, F. A., Ko, E. M., Walker, N. J., Arzi, B., Tepper, C. G., et al. (2017). Human and feline adipose-derived mesenchymal stem cells have comparable phenotype, immunomodulatory functions, and transcriptome. Stem Cell Res. Ther. 8:69. doi: 10.1186/s13287-017-0528-z

Clark, K. C., Kol, A., Shahbenderian, S., Granick, J. L., Walker, N. J., and Borjesson, D. L. (2016). Canine and equine mesenchymal stem cells grown in serum free media have altered immunophenotype. Stem Cell Rev. Rep. 12, 245-256. doi: 10.1007/s12015-015-9638-0

Cooray, S. (2004). The pivotal role of phosphatidylinositol 3-kinase-Akt signal transduction in virus survival. J. Gen. Virol. 85, 1065-1076. doi: 10.1099/vir. 0.19771-0

Costa, L. A., Eiro, N., Fraile, M., Gonzalez, L. O., Saá, J., Garcia-Portabella, P., et al. (2020). Functional heterogeneity of mesenchymal stem cells from natural niches to culture conditions: implications for further clinical uses. Cell. Mol. Life Sci. 78, 447-467. doi: 10.1007/s00018-020-03600-0

Curtis, T. M., Hannett, J. M., Harman, R. M., Puoplo, N. A., and Van de Walle, G. R. (2018). The secretome of adipose-derived mesenchymal stem cells protects SH-SY5Y cells from arsenic-induced toxicity, independent of a neuron-like differentiation mechanism. NeuroTox 67, 54-64. doi: 10.1016/j.neuro.2018. 04.009

Damania, A., Jaiman, D., Teotia, A. K., and Kumar, A. (2018). Mesenchymal stromal cell-derived exosome-rich fractionated secretome confers a hepatoprotective effect in liver injury. Stem Cell Res. Ther. 9:31. doi: 10.1186/ s13287-017-0752-6

Dane, D. M., Cao, K., Zhang, Y.-A., Kernstine, K. H., Gazdhar, A., Geiser, T., et al. (2020). Inhalational delivery of induced pluripotent stem cell secretome improves postpneumonectomy lung structure and function. J. Appl. Physiol. 129, 1051-1061. doi: 10.1152/japplphysiol.00205.2020

Daneshmandi, L., Shah, S., Jafari, T., Bhattacharjee, M., Momah, D., SavehShemshaki, N., et al. (2020). Emergence of the stem cell secretome in regenerative engineering. Trends Biotechnol. 38, 1373-1384. doi: 10.1016/j. tibtech.2020.04.013

de la Garza-Rodea, A. S., Verweij, M. C., Boersma, H., van der Velde-van Dijke, I., de Vries, A. A., Hoeben, R. C., et al. (2011). Exploitation of herpesvirus immune evasion strategies to modify the immunogenicity of human mesenchymal stem cell transplants. PLoS One 6:e14493. doi: 10.1371/journal.pone.0014493

de Moraes, C. N., Maia, L., de Oliveira, E., de Paula Freitas, Dell'Aqua, C., Chapwanya, A., et al. (2017). Shotgun proteomic analysis of the secretome of bovine endometrial mesenchymal progenitor/stem cells challenged or not with bacterial lipopolysaccharide. Vet. Immunol. Immnopathol. 187, 42-47. doi: 10.1016/j.vetimm.2017.03.007

De Schauwer, C., Van de Walle, G. R., Van Soom, A., and Meyer, E. (2013). Mesenchymal stem cell therapy in horses: useful beyond orthopedic injuries? Vet. Quarter 33, 234-241. doi: 10.1080/01652176.2013.800250

DelaRosa, O., and Lombardo, E. (2010). Modulation of adult mesenchymal stem cells activity by toll-like receptors: implications on therapeutic potential. Med. Inflamm. 2010:865601. doi: 10.1155/2010/865601

Devireddy, L. R., Boxer, L., Myers, M. J., Skasko, M., and Screven, R. (2017). Questions and challenges in the development of mesenchymal stromal/stem cell-based therapies in veterinary medicine. Tissue Eng. Part B Rev. 23, 462-470. doi: $10.1089 /$ ten.teb.2016.0451

Dias, I. E., Pinto, P. O., Barros, L. C., Viegas, C. A., Dias, I. R., and Carvalho, P. P. (2019). Mesenchymal stem cells therapy in companion animals: useful for immune-mediated diseases? BMC Vet. Res. 15:358. doi: 10.1186/s12917-0192087-2

Dothel, G., Bernardini, C., Zannoni, A., Spirito, M. R., Salaroli, R., Bacci, M. L., et al. (2019). Ex vivo effect of vascular wall stromal cells secretome on enteric ganglia. World J. Gastroentrol. 25, 4892-4903. doi: 10.3748/wjg.v25.i33.4892

Eirin, A., Zhu, X.-Y., Puranik, A. S., Woollard, J. R., Tang, H., Dasari, S., et al. (2017). Integrated transcriptomic and proteomic analysis of the molecular 
cargo of extracellular vesicles derived from porcine adipose tissue-derived mesenchymal stem cells. PLoS One 12:e0174303. doi: 10.1371/journal.pone. 0174303

Eleuteri, S., and Fierabracci, A. (2019). Insights into the secretome of mesenchymal stem cells and its potential applications. Int. J. Mol. Sci. 20:4597. doi: 10.3390/ ijms20184597

Eljarrah, A., Gergues, M., Pobiarzyn, P. W., Sandiford, O. A., and Rameshwar, P. (2019). "Therapeutic potential of mesenchymal stem cells in immune-mediated diseases," in Stem Cells Advances in Experimental Medicine and Biology, ed. M. Z. Ratajczak (Cham: Springer International Publishing), 93-108. doi: 10. 1007/978-3-030-31206-0_5

Endo, K., Fujita, N., Nakagawa, T., and Nishimura, R. (2019). Effect of fibroblast growth factor-2 and serum on canine mesenchymal stem cell chondrogenesis. Tiss. Eng. Part A 25, 901-910. doi: 10.1089/ten.TEA.2018.0177

Ferro, F., Spelat, R., Shaw, G., Duffy, N., Islam, M. N., O'Shea, P. M., et al. (2019). Survival/adaptation of bone marrow-derived mesenchymal stem cells after long-term starvation through selective processes. Stem Cells 37, 813-827. doi: 10.1002/stem.2998

Freeman, B. T., Jung, J. P., and Ogle, B. M. (2015). Single-Cell RNA-Seq of bone marrow-derived mesenchymal stem cells reveals unique profiles of lineage priming. PLoS One 10:e0136199. doi: 10.1371/journal.pone.0136199

Gabner, S., Ertl, R., Velde, K., Renner, M., Jenner, F., Egerbacher, M., et al. (2018). Cytokine-induced interleukin-1 receptor antagonist protein expression in genetically engineered equine mesenchymal stem cells for osteoarthritis treatment. J. Gene Med. 20:e3021. doi: 10.1002/jgm.3021

Gabner, S., Hlavaty, J., Velde, K., Renner, M., Jenner, F., and Egerbacher, M. (2016). Inflammation-induced transgene expression in genetically engineered equine mesenchymal stem cells. J. Gene Med. 18, 154-164. doi: 10.1002/jgm.2888

Galipeau, J., and Sensébé, L. (2018). Mesenchymal stromal cells: clinical challenges and therapeutic opportunities. Cell Stem Cell 22, 824-833. doi: 10.1016/j.stem. 2018.05.004

Garcia-Castro, J., Alemany, R., Cascallo, M., Martinez-Quintanilla, J., del Mar, Arriero, M., et al. (2010). Treatment of metastatic neuroblastoma with systemic oncolytic virotherapy delivered by autologous mesenchymal stem cells: an exploratory study. Cancer Gene Ther. 17, 476-483. doi: 10.1038/cgt.2010.4

Geburek, F., Roggel, F., van Schie, H. T. M., Beineke, A., Estrada, R., Weber, K., et al. (2017). Effect of single intralesional treatment of surgically induced equine superficial digital flexor tendon core lesions with adipose-derived mesenchymal stromal cells: a controlled experimental trial. Stem Cell Res. Ther. 8:129. doi: 10.1186/s13287-017-0564-8

Gowen, A., Shahjin, F., Chand, S., Odegaard, K. E., and Yelamanchili, S. V. (2020). Mesenchymal stem cell-derived extracellular vesicles: challenges in clinical applications. Front. Cell Dev. Biol. 8:149. doi: 10.3389/fcell.2020.00149

Grinblat, G. A., Khan, R. S., Dine, K., Wessel, H., Brown, L., and Shindler, K. S. (2018). RGC neuroprotection following optic nerve trauma mediated by intranasal delivery of amnion cell secretome. Invest. Ophthalmol. Vis. Sci. 59, 2470-2477. doi: 10.1167/iovs.18-24096

Gugjoo, M. B., Amarpal, Fazili, M. R., Shah, R. A., and Sharma, G. T. (2019). Mesenchymal stem cell: Basic research and potential applications in cattle and buffalo. J. Cell Physiol. 234, 8618-8635. doi: 10.1002/jcp.27846

Hamann, A., Nguyen, A., and Pannier, A. K. (2019). Nucleic acid delivery to mesenchymal stem cells: a review of nonviral methods and applications. J. Biol. Eng. 13:7. doi: 10.1186/s13036-019-0140-0

Han, S. M., Kim, H. T., Kim, K. W., Jeon, K. O., Seo, K. W., Choi, E. W., et al. (2015a). CTLA4 overexpressing adipose tissue-derived mesenchymal stem cell therapy in a dog with steroid-refractory pemphigus foliaceus. BMC Vet. Res. 11:49. doi: 10.1186/s12917-015-0371-3

Han, S. M., Park, C. W., Ahn, J. O., Park, S. C., Jung, W. S., Seo, K. W., et al. (2015b). Pro-apoptotic and growth-inhibitory effect of IFN- $\beta$-overexpressing canine adipose tissue-derived mesenchymal stem cells against melanoma cells. Anticancer Res. 35, 4749-4756.

Harman, R. M., Bihun, I. V., and Van de Walle, G. R. (2017a). Secreted factors from equine mesenchymal stromal cells diminish the effects of TGF- $\beta 1$ on equine dermal fibroblasts and alter the phenotype of dermal fibroblasts isolated from cutaneous fibroproliferative wounds: Mesenchymal stromal cell effects on fibroblasts. Wound Rep. Reg. 25, 234-247. doi: 10.1111/wrr.12515

Harman, R. M., He, M. K., Zhang, S., and Van De Walle, G. R. (2018). Plasminogen activator inhibitor-1 and tenascin-C secreted by equine mesenchymal stromal cells stimulate dermal fibroblast migration in vitro and contribute to wound healing in vivo. Cytotherapy 20, 1061-1076. doi: 10.1016/j.jcyt.2018.06.005

Harman, R. M., Patel, R. S., Fan, J. C., Park, J. E., Rosenberg, B. R., and Van de Walle, G. R. (2020). Single-cell RNA sequencing of equine mesenchymal stromal cells from primary donor-matched tissue sources reveals functional heterogeneity in immune modulation and cell motility. Stem Cell Res. Ther. 11:524. doi: 10.1186/s13287-020-02043-5

Harman, R. M., Theoret, C. L., and Van de Walle, G. R. (2019). The horse as a model for the study of cutaneous wound healing. Adv. Wound Care Wound doi: 10.1089/wound.2018.0883 [Epub ahead of print].

Harman, R. M., Yang, S., He, M. K., and Van de Walle, G. R. (2017b). Antimicrobial peptides secreted by equine mesenchymal stromal cells inhibit the growth of bacteria commonly found in skin wounds. Stem Cell Res. Ther. 8:157. doi: 10.1186/s13287-017-0610-6

Harrell, C., Fellabaum, C., Jovicic, N., Djonov, V., Arsenijevic, N., and Volarevic, V. (2019). Molecular mechanisms responsible for therapeutic potential of mesenchymal stem cell-derived secretome. Cells 8:467. doi: 10.3390/ cells 8050467

Haynesworth, S. E., Baber, M. A., and Caplan, A. I. (1996). Cytokine expression by human marrow-derived mesenchymal progenitor cells in vitro: effects of dexamethasone and IL-1 alpha. J. Cell Physiol. 166, 585-592. doi: 10.1002/(SICI) 1097-4652(199603)166:3<585:AID-JCP13<3.0.CO;2-6

He, L., and Hannon, G. J. (2004). MicroRNAs: small RNAs with a big role in gene regulation. Nat. Rev. Genet. 5, 522-531. doi: 10.1038/nrg1379

Heidari, B., Shirazi, A., Akhondi, M. M., Hassanpour, H., Behzadi, B., Naderi, M. M., et al. (2013). Comparison of proliferative and multilineage differentiation potential of sheep mesenchymal stem cells derived from bone marrow, liver, and adipose tissue. Avicenna J. Med. Biotechnol. 5, 104-117.

Hill, A. B. T., Bressan, F. F., Murphy, B. D., and Garcia, J. M. (2019). Applications of mesenchymal stem cell technology in bovine species. Stem Cell Res. Ther. 10:44. doi: 10.1186/s13287-019-1145-9

Hill, J. A., Cassano, J. M., Goodale, M. B., and Fortier, L. A. (2017). Antigenicity of mesenchymal stem cells in an inflamed joint environment. Am. J. Vet. Res. 78, 867-875. doi: 10.2460/ajvr.78.7.867

Hoffman, A. M., and Dow, S. W. (2016). Concise review: stem cell trials using companion animal disease models: stem cell trials in companion animal diseases. Stem Cells 34, 1709-1729. doi: 10.1002/stem.2377

Huang, Y., Li, Q., Zhang, K., Hu, M., Wang, Y., Du, L., et al. (2019). Single cell transcriptomic analysis of human mesenchymal stem cells reveals limited heterogeneity. Cell Death Dis. 10:368. doi: 10.1038/s41419-019-1583-4

Iida, Y., Yoshikawa, R., Murata, A., Kotani, H., Kazuki, Y., Oshimura, M., et al. (2020). Local injection of CCL19-expressing mesenchymal stem cells augments the therapeutic efficacy of anti-PD-L1 antibody by promoting infiltration of immune cells. J. Immunother. Cancer 8:e00582. doi: 10.1136/jitc-2020000582

Islam, A., Urbarova, I., Bruun, J. A., and Martinez-Zubiaurre, I. (2019). Largescale secretome analyses unveil the superior immunosuppressive phenotype of umbilical cord stromal cells as compared to other adult mesenchymal stromal cells. Eur. Cell Mater. 37, 153-174. doi: 10.22203/eCM.v037a10

Jaimes, Y., Naaldijk, Y., Wenk, K., Leovsky, C., and Emmrich, F. (2017). Mesenchymal stem cell-derived microvesicles modulate lipopolysaccharidesinduced inflammatory responses to microglia cells: MSC-MVs modulate lpsinduced microglia responses. Stem Cells 35, 812-823. doi: 10.1002/stem.2541

Jang, B. J., Byeon, Y. E., Lim, J. H., Ryu, H. H., Kim, W. H., Koyama, Y., et al. (2008). Implantation of canine umbilical cord blood-derived mesenchymal stem cells mixed with beta-tricalcium phosphate enhances osteogenesis in bone defect model dogs. J. Vet. Sci. 9, 387-393. doi: 10.4142/jvs.2008.9.4.387

Jervis, M., Huaman, O., Cahuascanco, B., Bahamonde, J., Cortez, J., Arias, J. I., et al. (2019). Comparative analysis of in vitro proliferative, migratory and proangiogenic potentials of bovine fetal mesenchymal stem cells derived from bone marrow and adipose tissue. Vet. Res. Commun. 43, 165-178. doi: 10.1007/ s11259-019-09757-9

Jin, Z., Ren, J., and Qi, S. (2020). Human bone mesenchymal stem cells-derived exosomes overexpressing microRNA-26a-5p alleviate osteoarthritis via downregulation of PTGS2. Int. Immunopharmy 78:105946. doi: 10.1016/j.intimp. 2019.105946

Jitschin, R., Böttcher, M., Saul, D., Lukassen, S., Bruns, H., Loschinski, R., et al. (2019). Inflammation-induced glycolytic switch controls suppressivity of 
mesenchymal stem cells via STAT1 glycosylation. Leukemia 33, 1783-1796. doi: 10.1038/s41375-018-0376-6

Johnson, V., Webb, T., Norman, A., Coy, J., Kurihara, J., Regan, D., et al. (2017). Activated mesenchymal stem cells interact with antibiotics and host innate immune responses to control chronic bacterial infections. Sci. Rep. 7:9575. doi: 10.1038/s41598-017-08311-4

Jung, J., Jeong, J., and Hong, H. S. (2019). Substance P improves MSC-mediated RPE regeneration by modulating PDGF-BB. Biochem. Biophys. Res. Commun. 515, 524-530. doi: 10.1016/j.bbrc.2019.05.186

Kehl, D., Generali, M., Mallone, A., Heller, M., Uldry, A.-C., Cheng, P., et al. (2019). Proteomic analysis of human mesenchymal stromal cell secretomes: a systematic comparison of the angiogenic potential. npj Regen. Med. 4:8. doi: 10.1038/s41536-019-0070-y

Khan, R. S., Dine, K., Bauman, B., Lorentsen, M., Lin, L., Brown, H., et al. (2017). Intranasal delivery of a novel amnion cell secretome prevents neuronal damage and preserves function in a mouse multiple sclerosis model. Sci. Rep. 7:41768. doi: $10.1038 /$ srep41768

Khatri, M., O’Brien, T. D., Chattha, K. S., and Saif, L. J. (2015). Porcine lung mesenchymal stromal cells possess differentiation and immunoregulatory properties. Stem Cell Res. Ther. 6:222. doi: 10.1186/s13287-0150220-0

Khatri, M., Richardson, L. A., and Meulia, T. (2018). Mesenchymal stem cellderived extracellular vesicles attenuate influenza virus-induced acute lung injury in a pig model. Stem Cell Res. Ther. 9:17. doi: 10.1186/s13287-0180774-8

Kim, K. H., Lee, J. I., Kim, O. H., Hong, H. E., Kwak, B. J., Choi, H. J., et al. (2019). Ameliorating liver fibrosis in an animal model using the secretome released from miR-122-transfected adipose-derived stem cells. World J. Stem Cell 11, 990-1004. doi: 10.4252/wjsc.v11.i11.990

Kim, S. M., Li, Q., An, J. H., Chae, H. K., Yang, J. I., Ryu, M. O., et al. (2019). Enhanced angiogenic activity of dimethyloxalylglycine-treated canine adipose tissue-derived mesenchymal stem cells. J. Vet. Med. Sci. 81, 1663-1670. doi: 10.1292/jvms.19-0337

Klier, J., Bartl, C., Geuder, S., Geh, K. J., Reese, S., Goehring, L. S., et al. (2019). Immunomodulatory asthma therapy in the equine animal model: a doseresponse study and evaluation of a long-term effect. Immun. Inflamm. Dis. 7, 130-149. doi: 10.1002/iid3.252

Kol, A., Foutouhi, S., Walker, N. J., Kong, N. T., Weimer, B. C., and Borjesson, D. L. (2014). Gastrointestinal microbes interact with canine adipose-derived mesenchymal stem cells in vitro and enhance immunomodulatory functions. Stem Cells Dev. 23, 1831-1843. doi: 10.1089/scd.2014.0128

Kompa, A. R., Greening, D. W., Kong, A. M., McMillan, P. J., Fang, H., Saxena, R., et al. (2020). Sustained subcutaneous delivery of secretome of human cardiac stem cells promotes cardiac repair following myocardial infarction. Cardiovasc. Res. 117, 918-929. doi: 10.1093/cvr/cvaa088

Kosol, W., Kumar, S., Marrero-BerrÍos, I., and Berthiaume, F. (2020). Medium conditioned by human mesenchymal stromal cells reverses low serum and hypoxia-induced inhibition of wound closure. Biochem. Biophys. Res. Commun. 522, 335-341. doi: 10.1016/j.bbrc.2019.11.071

Krueger, T. E. G., Thorek, D. L. J., Denmeade, S. R., Isaacs, J. T., and Brennen, W. N. (2018). Concise review: mesenchymal stem cell-based drug delivery: the good, the bad, the ugly, and the promise. Stem Cells Transl. Med. 7, 651-663. doi: $10.1002 /$ sctm.18-0024

Lange-Consiglio, A., Lazzari, B., Pizzi, F., Stella, A., Girani, A., Quintè, A., et al. (2018). Different culture times affect microrna cargo in equine amniotic mesenchymal cells and their microvesicles. Tiss. Eng. Part C Method 24, 596604. doi: 10.1089/ten.tec.2018.0205

Lee, J., Byeon, J. S., Lee, K. S., Gu, N. Y., Lee, G. B., Kim, H. R., et al. (2016). Chondrogenic potential and anti-senescence effect of hypoxia on canine adipose mesenchymal stem cells. Vet. Res. Commun. 40, 1-10. doi: 10.1007/ s11259-015-9647-0

Li, G.-C., Ye, Q.-H., Xue, Y.-H., Sun, H.-J., Zhou, H.-J., Ren, N., et al. (2010). Human mesenchymal stem cells inhibit metastasis of a hepatocellular carcinoma model using the MHCC97-H cell line. Cancer Sci. 101, 2546-2553. doi: 10.1111/j.1349-7006.2010.01738.x

Li, J., Ezzelarab, M. B., Ayares, D., and Cooper, D. K. C. (2014). The potential role of genetically modified pig mesenchymal stromal cells in xenotransplantation. Stem Cell Rev. Rep. 10, 79-85. doi: 10.1007/s12015-013-9478-8
Li, X., He, L., Yue, Q., Lu, J., Kang, N., Xu, X., et al. (2017). MiR-9-5p promotes MSC migration by activating $\beta$-catenin signaling pathway. Am. J. Physiol. Cell Physiol. 313, C80-C93. doi: 10.1152/ajpcell.00232.2016

Liang, M., Liu, W., Peng, Z., Lv, S., Guan, Y., An, G., et al. (2019). The therapeutic effect of secretome from human umbilical cord-derived mesenchymal stem cells in age-related osteoporosis. Art Cells Nanomed. Biotech. 47, 1357-1366. doi: 10.1080/21691401.2019.1596945

Liang, X., Zhang, L., Wang, S., Han, Q., and Zhao, R. C. (2016). Exosomes secreted by mesenchymal stem cells promote endothelial cell angiogenesis by transferring miR-125a. J. Cell Sci. 129, 2182-2189. doi: 10.1242/jcs.170373

Liao, Y., Lei, J., Liu, M., Lin, W., Hong, D., Tuo, Y., et al. (2016). Mesenchymal stromal cells mitigate experimental colitis via insulin-like growth factor binding protein 7-mediated immunosuppression. Mol. Ther. 24, 1860-1872. doi: 10. $1038 / \mathrm{mt} .2016 .140$

Liesveld, J. L., Sharma, N., and Aljitawi, O. S. (2020). Stem cell homing: from physiology to therapeutics. Stem Cells 38, 1241-1253. doi: 10.1002/stem.3242

Lukomska, B., Stanaszek, L., Zuba-Surma, E., Legosz, P., Sarzynska, S., and Drela, K. (2019). Challenges and controversies in human mesenchymal stem cell therapy. Stem Cells Int. 2019:9628536. doi: 10.1155/2019/9628536

MacDonald, E. S., and Barrett, J. G. (2020). The potential of mesenchymal stem cells to treat systemic inflammation in horses. Front. Vet. Sci. 6:507. doi: 10. 3389/fvets.2019.00507

Magne, B., Dedier, M., Nivet, M., Coulomb, B., Banzet, S., Lataillade, J. J., et al. (2020). IL-1 $\beta$-primed mesenchymal stromal cells improve epidermal substitute engraftment and wound healing via matrix metalloproteinases and transforming growth Factor- $\beta 1$. J. Invest. Dermatol. 140, 688.e21-698.e21. doi: 10.1016/j.jid.2019.07.721

Maguire, G. (2013). Stem cell therapy without the cells. Commun. Integr. Biol. 6:e26631. doi: $10.4161 /$ cib.26631

Mancuso, P., Raman, S., Glynn, A., Barry, F., and Murphy, J. M. (2019). Mesenchymal stem cell therapy for osteoarthritis: the critical role of the cell secretome. Front. Bioeng.. Biotechnol. 7:9. doi: 10.3389/fbioe.2019.00009

Marcu, K. B., Otero, M., Olivotto, E., Borzi, R. M., and Goldring, M. B. (2010). NFkappaB signaling multiple angles to target OA. Curr. Drug Targets 11, 599-613. doi: 10.2174/138945010791011938

Marquass, B., Schulz, R., Hepp, P., Zscharnack, M., Aigner, T., Schmidt, S., et al. (2011). Matrix-associated implantation of predifferentiated mesenchymal stem cells versus articular chondrocytes: in vivo results of cartilage repair after 1 year. Am. J. Sports Med. 39, 1401-1412. doi: 10.1177/0363546511398646

Martin, I., Galipeau, J., Kessler, C., Le Blanc, K., and Dazzi, F. (2019). Challenges for mesenchymal stromal cell therapies. Sci. Transl. Med. 11:eaat2189. doi: 10.1126/scitranslmed.aat2189

Marx, C., Gardner, S., Harman, R. M., and Van de Walle, G. R. (2020). The mesenchymal stromal cell secretome impairs methicillin-resistant Staphylococcus aureus biofilms via cysteine protease activity in the equine model. Stem Cell Transl. Med. 9, 746-757. doi: 10.1002/sctm.19-0333

Matuskova, M., Kozovska, Z., Toro, L., Durinikova, E., Tyciakova, S., Cierna, Z., et al. (2015). Combined enzyme/prodrug treatment by genetically engineered AT-MSC exerts synergy and inhibits growth of MDA-MB-231 induced lung metastases. J. Exp. Clin. Cancer Res. 34:33. doi: 10.1186/s13046-0150149-2

Mayourian, J., Ceholski, D. K., Gorski, P. A., Mathiyalagan, P., Murphy, J. F., Salazar, S. I., et al. (2018). Exosomal microRNA-21-5p mediates mesenchymal stem cell paracrine effects on human cardiac tissue contractility. Circ. Res. 122, 933-944. doi: 10.1161/CIRCRESAHA.118.312420

McCoy, A. M. (2015). Animal models of osteoarthritis: comparisons and key considerations. Vet. Pathol. 52, 803-818. doi: 10.1177/0300985815588611

Mead, B., Chamling, X., Zack, D. J., Ahmed, Z., and Tomarev, S. (2020). TNF $\alpha-$ mediated priming of mesenchymal stem cells enhances their neuroprotective effect on retinal ganglion cells. Invest. Ophthalmol. Vis. Sci. 61:6. doi: 10.1167/ iovs.61.2.6

Meeusen, E. N., Snibson, K. J., Hirst, S. J., and Bischof, R. J. (2009). Sheep as a model species for the study and treatment of human asthma and other respiratory diseases. Drug Discov. Today Dis. Models 6, 101-106. doi: 10.1016/j.ddmod. 2009.12.002

Melen, G. J., Franco-Luzón, L., Ruano, D., González-Murillo, Á, Alfranca, A., Casco, F., et al. (2016). Influence of carrier cells on the clinical outcome of children with neuroblastoma treated with high dose of oncolytic adenovirus 
delivered in mesenchymal stem cells. Cancer Lett. 371, 161-170. doi: 10.1016/j. canlet.2015.11.036

Mendes-Pinheiro, B., Anjo, S. I., Manadas, B., Da Silva, J. D., Marote, A., Behie, L. A., et al. (2019). Bone marrow mesenchymal stem cells' secretome exerts neuroprotective effects in a Parkinson's disease rat model. Front. Bioeng. Biotechnol. 7:294. doi: 10.3389/fbioe.2019.00294

Miranda, J. P., Camões, S. P., Gaspar, M. M., Rodrigues, J. S., Carvalheiro, M., Bárcia, R. N., et al. (2019). The secretome derived from 3D-cultured umbilical cord tissue MSCs counteracts manifestations typifying rheumatoid arthritis. Front. Immunol. 10:18. doi: 10.3389/fimmu.2019.00018

Mitchell, R., Mellows, B., Sheard, J., Antonioli, M., Kretz, O., Chambers, D., et al. (2019). Secretome of adipose-derived mesenchymal stem cells promotes skeletal muscle regeneration through synergistic action of extracellular vesicle cargo and soluble proteins. Stem Cell Res. Ther. 10:116. doi: 10.1186/s13287-019-1213-1

Mohamad-Fauzi, N., Ross, P. J., Maga, E. A., and Murray, J. D. (2015). Impact of source tissue and ex vivo expansion on the characterization of goat mesenchymal stem cells. J. Anim. Sci. Biotechnol. 6:1. doi: 10.1186/2049-18 91-6-1

Moll, G., Hoogduijn, M. J., and Ankrum, J. A. (2020). Editorial: safety, efficacy and mechanisms of action of mesenchymal stem cell therapies. Front. Immunol. 11:243. doi: $10.3389 /$ fimmu. 2020.00243

Mumaw, J. L., Schmiedt, C. W., Breidling, S., Sigmund, A., Norton, N. A., Thoreson, M., et al. (2015). Feline mesenchymal stem cells and supernatant inhibit reactive oxygen species production in cultured feline neutrophils. Res. Vet. Sci. 103, 60-69. doi: 10.1016/j.rvsc.2015.09.010

Mun, J. Y., Shin, K. K., Kwon, O., Lim, Y. T., and Oh, D. B. (2016). Minicircle microporation-based non-viral gene delivery improved the targeting of mesenchymal stem cells to an injury site. Biomaterial 101, 310-320. doi: 10.1016/j.biomaterials.2016.05.057

Murphy, N., Treacy, O., Lynch, K., Morcos, M., Lohan, P., Howard, L., et al. (2019). TNF- $\alpha /$ IL- $1 \beta$-licensed mesenchymal stromal cells promote corneal allograft survival via myeloid cell-mediated induction of Foxp3(+) regulatory T cells in the lung. FASEB J. 33, 9404-9421. doi: 10.1096/fj.201900047R

Music, E., Futrega, K., and Doran, M. R. (2018). Sheep as a model for evaluating mesenchymal stem/stromal cell (MSC)-based chondral defect repair. Osteoarthritis Cartilage 26, 730-740. doi: 10.1016/j.joca.2018.03.006

Najar, M., Ouhaddi, Y., Bouhtit, F., Melki, R., Afif, H., Boukhatem, N., et al. (2019). Empowering the immune fate of bone marrow mesenchymal stromal cells: gene and protein changes. Inflamm. Res.? 68, 167-176. doi: 10.1007/s00011-018$1198-8$

Niada, S., Giannasi, C., Gomarasca, M., Stanco, D., Casati, S., and Brini, A. T. (2019). Adipose-derived stromal cell secretome reduces TNF $\alpha$-induced hypertrophy and catabolic markers in primary human articular chondrocytes. Stem Cell Res. 38:101463. doi: 10.1016/j.scr.2019.101463

Noronha, N. C., Mizukami, A., Caliári-Oliveira, C., Cominal, J. G., Rocha, J. L. M., Covas, D. T., et al. (2019). Priming approaches to improve the efficacy of mesenchymal stromal cell-based therapies. Stem Cell Res. Ther. 10:131. doi: 10.1186/s13287-019-1224-y

Ocansey, D. K. W., Pei, B., Yan, Y., Qian, H., Zhang, X., Xu, W., et al. (2020). Improved therapeutics of modified mesenchymal stem cells: an update. J. Transl. Med. 18:42. doi: 10.1186/s12967-020-02234-x

Olivry, T. (2006). A review of autoimmune skin diseases in domestic animals: I - superficial pemphigus. Vet. Dermatol. 17, 291-305. doi: 10.1111/j.1365-3164. 2006.00540.x

Ophelders, D. R. M. G., Wolfs, T. G. A. M., Jellema, R. K., Zwanenburg, A., Andriessen, P., Delhaas, T., et al. (2016). Mesenchymal stromal cell-derived extracellular vesicles protect the fetal brain after hypoxia-ischemia. Stem Cells Transl. Med. 5, 754-763. doi: 10.5966/sctm.2015-0197

Parys, M., Kruger, J. M., and Yuzbasiyan-Gurkan, V. (2017). Evaluation of immunomodulatory properties of feline mesenchymal stem cells. Stem Cells Dev. 26, 776-785. doi: 10.1089/scd.2016.0041

Pittenger, M. F., Discher, D. E., Péault, B. M., Phinney, D. G., Hare, J. M., and Caplan, A. I. (2019). Mesenchymal stem cell perspective: cell biology to clinical progress. npj Regen. Med. 4:22. doi: 10.1038/s41536-019-0083-6

Pogue, B., Estrada, A. H., Sosa-Samper, I., Maisenbacher, H. W., Lamb, K. E., Mincey, B. D., et al. (2013). Stem-cell therapy for dilated cardiomyopathy: a pilot study evaluating retrograde coronary venous delivery. J. Small Anim. Pract. 54, 361-366. doi: 10.1111/jsap. 12098
Quimby, J. M., and Borjesson, D. L. (2018). Mesenchymal stem cell therapy in cats: current knowledge and future potential. J. Feline Med. Surg. 20, 208-216. doi: $10.1177 / 1098612 X 18758590$

Ragni, E., Perucca Orfei, C., De Luca, P., Mondadori, C., Viganò, M., Colombini, A., et al. (2020). Inflammatory priming enhances mesenchymal stromal cell secretome potential as a clinical product for regenerative medicine approaches through secreted factors and EV-miRNAs: the example of joint disease. Stem Cell Res. Ther. 11:165. doi: 10.1186/s13287-020-01677-9

Rajao, D. S., and Vincent, A. L. (2015). Swine as a model for influenza A virus infection and immunity. ILAR J. 56, 44-52. doi: 10.1093/ilar/ilv002

Reesink, H. L., Sutton, R. M., Shurer, C. R., Peterson, R. P., Tan, J. S., Su, J., et al. (2017). Galectin-1 and galectin-3 expression in equine mesenchymal stromal cells (MSCs), synovial fibroblasts and chondrocytes, and the effect of inflammation on MSC motility. Stem Cell Res. Ther. 8:243. doi: 10.1186/s13287017-0691-2

Renzi, S., Riccò, S., Dotti, S., Sesso, L., Grolli, S., Cornali, M., et al. (2013). Autologous bone marrow mesenchymal stromal cells for regeneration of injured equine ligaments and tendons: a clinical report. Res. Vet. Sci. 95, 272-277. doi: 10.1016/j.rvsc.2013.01.017

Rizk, M., Monaghan, M., Shorr, R., Kekre, N., Bredeson, C. N., and Allan, D. S. (2016). Heterogeneity in studies of mesenchymal stromal cells to treat or prevent graft-versus-host disease: a scoping review of the evidence. Biol. Blood Marrow Transpl. 22, 1416-1423. doi: 10.1016/j.bbmt.2016.04.010

Rodríguez-Milla, M., Morales-Molina, A., Perisé-Barrios, A. J., Cejalvo, T., and García-Castro, J. (2020). AKT and JUN are differentially activated in mesenchymal stem cells after infection with human and canine oncolytic adenoviruses. Cancer Gene Ther. 28, 64-73. doi: 10.1038/s41417-020-0184-9

Roth, J. A., and Tuggle, C. K. (2015). Livestock models in translational medicine. ILAR J. 56, 1-6. doi: 10.1093/ilar/ilv011

Rouhbakhshzaeri, M., Rabiee, B., Azar, N., Ghahari, E., Putra, I., Eslani, M., et al. (2019). New ex vivo model of corneal endothelial phacoemulsification injury and rescue therapy with mesenchymal stromal cell secretome. J. Cataract Refract. Surg. 45, 361-366. doi: 10.1016/j.jcrs.2018.09.030

Ruano, D., López-Martín, J. A., Moreno, L., Lassaletta, Á, Bautista, F., Andión, M., et al. (2020). First-in-human, first-in-child trial of autologous MSCs carrying the oncolytic virus Icovir-5 in patients with advanced tumors. Mol. Ther. 8, 1033-1042. doi: 10.1016/j.ymthe.2020.01.019

Russell, K. A., Chow, N. H. C., Dukoff, D., Gibson, T. W. G., LaMarre, J., Betts, D. H., et al. (2016). Characterization and immunomodulatory effects of canine adipose tissue- and bone marrow-derived mesenchymal stromal cells. PLoS One 11:e0167442. doi: 10.1371/journal.pone. 0167442

Ryu, N.-E., Lee, S.-H., and Park, H. (2019). Spheroid culture system methods and applications for mesenchymal stem cells. Cells 8:1620. doi: 10.3390/ cells 8121620

Saeedi, P., Halabian, R., and Fooladi, A. A. I. (2019). Antimicrobial effects of mesenchymal stem cells primed by modified LPS on bacterial clearance in sepsis. J. Cell Physiol. 234, 4970-4986. doi: 10.1002/jcp.27298

Sagaradze, G. D., Basalova, N. A., Kirpatovsky, V. I., Ohobotov, D. A., Grigorieva, O. A., Balabanyan, V., et al. (2019). Application of rat cryptorchidism model for the evaluation of mesenchymal stromal cell secretome regenerative potential. Biomed. Pharmacother. 109, 1428-1436. doi: 10.1016/j.biopha.2018.10.174

Sagaradze, G. D., Nimiritsky, P. P., Akopyan, Z. A., Makarevich, P. I., and Efimenko, A. Y. (2018). "Cell-free therapeutics' from components secreted by mesenchymal stromal cells as a novel class of biopharmaceuticals," in Biopharmaceuticals, eds M.-K. Yeh and Y.-C. Chen (London: InTech), doi: 10.5772/intechopen.78605

Salinas-Vera, Y., Marchat, L., Gallardo-Rincn, D., Ruiz-Garca, E., Astudillo-De, La Vega, H., et al. (2018). AngiomiRs: MicroRNAs driving angiogenesis in cancer (Review). Int. J. Mol. Med. 43, 657-670. doi: 10.3892/ijmm.2018.4003

Samaeekia, R., Rabiee, B., Putra, I., Shen, X., Park, Y. J., Hematti, P., et al. (2018). Effect of human corneal mesenchymal stromal cell-derived exosomes on corneal epithelial wound healing. Invest. Ophthalmol. Vis. Sci. 59:5194. doi: 10.1167/iovs.18-24803

Sanghani, A., Osagie-Clouard, L., Samizadeh, S., Coathup, M. J., Kalia, P., Di Silvio, L., et al. (2018). CXCR4 has the potential to enhance bone formation in osteopenic rats. Tiss. Eng A 24, 1775-1783. doi: 10.1089/ten.tea.2018.0121

Sanghani-Kerai, A., Coathup, M., Samazideh, S., Kalia, P., Silvio, L. D., Idowu, B., et al. (2017). Osteoporosis and ageing affects the migration of stem cells and 
this is ameliorated by transfection with CXCR4. Bone Joint Res. 6, 358-365. doi: 10.1302/2046-3758.66.BJR-2016-0259.R1

Sarko, D. K., and McKinney, C. E. (2017). Exosomes: origins and therapeutic potential for neurodegenerative disease. Front. Neurosci. 11:82. doi: 10.3389/ fnins.2017.00082

Sasao, T., Fukuda, Y., Yoshida, S., Miyabara, S., Kasashima, Y., Kuwano, A., et al. (2015). Population doubling level-dependent change of secreted glycosaminoglycan in equine bone marrow-derived mesenchymal stem cells. J. Equine Sci. 26, 73-80. doi: 10.1294/jes.26.73

Schnabel, L. V., Lynch, M. E., van der Meulen, M. C., Yeager, A. E., Kornatowski, M. A., and Nixon, A. J. (2009). Mesenchymal stem cells and insulin-like growth factor-I gene-enhanced mesenchymal stem cells improve structural aspects of healing in equine flexor digitorum superficialis tendons. J. Orthop. Res. 27, 1392-1398. doi: 10.1002/jor.20887

Seaton, M., Hocking, A., and Gibran, N. S. (2015). Porcine models of cutaneous wound healing. ILAR J. 56, 127-138. doi: 10.1093/ilar/ilv016

Seo, K. W., Lee, H. W., Oh, Y. I., Ahn, J. O., Koh, Y. R., Oh, S. H., et al. (2011). Anti-tumor effects of canine adipose tissue-derived mesenchymal stromal cellbased interferon- $\beta$ gene therapy and cisplatin in a mouse melanoma model. Cytotherapy 13, 944-955. doi: 10.3109/14653249.2011.584864

Serra, J., Alves, C. P. A., Brito, L., Monteiro, G. A., Cabral, J. M. S., Prazeres, D. M. F., et al. (2019). Engineering of human mesenchymal stem/stromal cells with vascular endothelial growth factor-encoding minicircles for angiogenic ex vivo gene therapy. Hum. Gene Ther. 30, 316-329. doi: 10.1089/hum.20 18.154

Sherman, A. B., Gilger, B. C., Berglund, A. K., and Schnabel, L. V. (2017). Effect of bone marrow-derived mesenchymal stem cells and stem cell supernatant on equine corneal wound healing in vitro. Stem Cell Res. Ther. 8:120. doi: $10.1186 / \mathrm{s} 13287-017-0577-3$

Shologu, N., Scully, M., Laffey, J. G., and O’Toole, D. (2018). Human mesenchymal stem cell secretome from bone marrow or adipose-derived tissue sources for treatment of hypoxia-induced pulmonary epithelial injury. IJMS 19:2996. doi: 10.3390/ijms19102996

Smith, R. K. W., Korda, M., Blunn, G. W., and Goodship, A. E. (2003). Isolation and implantation of autologous equine mesenchymal stem cells from bone marrow into the superficial digital flexor tendon as a potential novel treatment. Equine Vet. J. 35, 99-102. doi: 10.2746/042516403775467388

Soland, M. A., Bego, M. G., Colletti, E., Porada, C. D., Zanjani, E. D., St Jeor, S., et al. (2012). Modulation of human mesenchymal stem cell immunogenicity through forced expression of human cytomegalovirus us proteins. PLoS One 7:e36163. doi: 10.1371/journal.pone. 0036163

Spees, J. L., Lee, R. H., and Gregory, C. A. (2016). Mechanisms of mesenchymal stem/stromal cell function. Stem Cell Res. Ther. 7:125. doi: 10.1186/s13287-0160363-7

Steffen, F., Bertolo, A., Affentranger, R., Ferguson, S. J., and Stoyanov, J. (2019). Treatment of naturally degenerated canine lumbosacral intervertebral discs with autologous mesenchymal stromal cells and collagen microcarriers: a prospective clinical study. Cell Transpl. 28, 201-211. doi: 10.1177/ 0963689718815459

Su, N., Jiang, L. Y., Wang, X., Gao, P. L., Zhou, J., Wang, C. Y., et al. (2019). Membrane-binding adhesive particulates enhance the viability and paracrine function of mesenchymal cells for cell-based therapy. Biomacromolecules 20, 1007-1017. doi: 10.1021/acs.biomac.8b01624

Sullivan, T. P., Eaglstein, W. H., Davis, S. C., and Mertz, P. (2001). The pig as a model for human wound healing. Wound Repair Regen. 9, 66-76. doi: 10.1046/ j.1524-475x.2001.00066.x

Sultana, T., Lee, S., Yoon, H.-Y., and Lee, J. I. (2018). Current status of canine umbilical cord blood-derived mesenchymal stem cells in veterinary medicine. Stem Cells Int. 2018:8329174. doi: 10.1155/2018/8329174

Sun, C., Wang, L., Wang, H., Huang, T., Yao, W., Li, J., et al. (2020). Singlecell RNA-seq highlights heterogeneity in human primary Wharton's jelly mesenchymal stem/stromal cells cultured in vitro. Stem Cell Res. Ther. 11:149. doi: $10.1186 / \mathrm{s} 13287-020-01660-4$

Sun, D. Z., Abelson, B., Babbar, P., and Damaser, M. S. (2019). Harnessing the mesenchymal stem cell secretome for regenerative urology. Nat. Rev. Urol. 16, 363-375. doi: 10.1038/s41585-019-0169-3

Taechangam, N., Iyer, S. S., Walker, N. J., Arzi, B., and Borjesson, D. L. (2019). Mechanisms utilized by feline adipose-derived mesenchymal stem cells to inhibit T lymphocyte proliferation. Stem Cell Res. Ther. 10:188. doi: 10.1186/ s13287-019-1300-3

Tao, X., Sun, M., Chen, M., Ying, R., Su, W., Zhang, J., et al. (2019). HMGB1modified mesenchymal stem cells attenuate radiation-induced vascular injury possibly via their high motility and facilitation of endothelial differentiation. Stem Cell Res. Ther. 10:92. doi: 10.1186/s13287-019-1197-x

Teshima, T., Matsumoto, H., and Koyama, H. (2018). Soluble factors from adipose tissue-derived mesenchymal stem cells promote canine hepatocellular carcinoma cell proliferation and invasion. PLoS One 13:e0191539. doi: 10.1371/ journal.pone.0191539

Ullah, M., Liu, D. D., and Thakor, A. S. (2019). Mesenchymal stromal cell homing: mechanisms and strategies for improvement. iScience 15, 421-438. doi: 10.1016/ j.isci.2019.05.004

Vasandan, A. B., Jahnavi, S., Shashank, C., Prasad, P., Kumar, A., and Prasanna, S. J. (2016). Human Mesenchymal stem cells program macrophage plasticity by altering their metabolic status via a PGE2-dependent mechanism. Sci. Rep. 6:38308. doi: $10.1038 /$ srep 38308

Villatoro, A. J., Alcoholado, C., Martín-Astorga, M. C., Fernández, V., Cifuentes, M., and Becerra, J. (2019). Comparative analysis and characterization of soluble factors and exosomes from cultured adipose tissue and bone marrow mesenchymal stem cells in canine species. Vet. Immunol. Immunopath. 208, 6-15. doi: 10.1016/j.vetimm.2018.12.003

Vizoso, F. J., Eiro, N., Cid, S., Schneider, J., and Perez-Fernandez, R. (2017). Mesenchymal stem cell secretome: toward cell-free therapeutic strategies in regenerative medicine. Int. J. Mol. Sci. 18:1852. doi: 10.3390/ijms18091852

von Einem, J. C., Guenther, C., Volk, H. D., Grütz, G., Hirsch, D., Salat, C., et al. (2019). Treatment of advanced gastrointestinal cancer with genetically modified autologous mesenchymal stem cells: results from the phase 1/2 TREAT-ME-1 trial. Int. J. Cancer 145, 1538-1546. doi: 10.1002/ijc.32230

von Einem, J. C., Peter, S., Günther, C., Volk, H. D., Grütz, G., Salat, C., et al. (2017). Treatment of advanced gastrointestinal cancer with genetically modified autologous mesenchymal stem cells - TREAT-ME-1 - a phase I, first in human, first in class trial. Oncotarget 8, 80156-80166. doi: 10.18632/oncotarget. 20964

Waas, M., and Kislinger, T. (2020). Addressing cellular heterogeneity in cancer through precision proteomics. J. Proteome Res. 19, 3607-3619. doi: 10.1021/acs. jproteome.0c00338

Wang, L., Qing, L., Liu, H., Liu, N., Qiao, J., Cui, C., et al. (2017). Mesenchymal stromal cells ameliorate oxidative stress-induced islet endothelium apoptosis and functional impairment via Wnt $4-\beta$-catenin signaling. Stem Cell Res. Ther. 8:188. doi: 10.1186/s13287-017-0640-0

Wei, Z., Qiao, S., Zhao, J., Liu, Y., Li, Q., Wei, Z., et al. (2019). miRNA181a over-expression in mesenchymal stem cell-derived exosomes influenced inflammatory response after myocardial ischemia-reperfusion injury. Life Sci. 232:116632. doi: 10.1016/j.lfs.2019.116632

Wiklander, O. P. B., Brennan, M. Á, Lötvall, J., Breakefield, X. O., and El Andaloussi, S. (2019). Advances in therapeutic applications of extracellular vesicles. Sci. Transl. Med. 11:eaav8521. doi: 10.1126/scitranslmed.aav8521

Willis, G. R., Fernandez-Gonzalez, A., Anastas, J., Vitali, S. H., Liu, X., Ericsson, M., et al. (2018). Mesenchymal stromal cell exosomes ameliorate experimental bronchopulmonary dysplasia and restore lung function through macrophage immunomodulation. Am. J. Resp. Crit. Care Med. 197, 104-116. doi: 10.1164/ rccm.201705-0925OC

Wilson, A., Webster, A., and Genever, P. (2019). Nomenclature and heterogeneity: consequences for the use of mesenchymal stem cells in regenerative medicine. Regen. Med. 14, 595-611. doi: 10.2217/rme-2018-0145

Worster, A. A., Brower-Toland, B. D., Fortier, L. A., Bent, S. J., Williams, J., and Nixon, A. (2001). Chondrocytic differentiation of mesenchymal stem cells sequentially exposed to transforming growth factor- $\beta 1$ in monolayer and insulin-like growth factor-I in a three-dimensional matrix. J. Orthop. Res. 19, 738-749. doi: 10.1016/s0736-0266(00)00054-1

Wu, X., Jiang, J., Zhongkai, Gu, Zhang, J., Chen, Y., et al. (2020). Mesenchymal stromal cell therapies: immunomodulatory properties and clinical progress. Stem Cell Res. Ther. 11:345. doi: 10.1186/s13287-020-01855-9

Xiang, C., Yang, K., Liang, Z., Wan, Y., Cheng, Y., Ma, D., et al. (2018). Sphingosine-1-phosphate mediates the therapeutic effects of bone marrow mesenchymal stem cell-derived microvesicles on articular cartilage defect. Transl. Res. 193, 42-53. doi: 10.1016/j.trsl.2017.12.003 
Xin, H., Katakowski, M., Wang, F., Qian, J. Y., Liu, X. S., Ali, M. M., et al. (2017). MicroRNA cluster miR-17-92 cluster in exosomes enhance neuroplasticity and functional recovery after stroke in rats. Stroke 48, 747-753. doi: 10.1161/ strokeaha.116.015204

Xin, H., Li, Y., Cui, Y., Yang, J. J., Zhang, Z. G., and Chopp, M. (2013). Systemic administration of exosomes released from mesenchymal stromal cells promote functional recovery and neurovascular plasticity after stroke in rats. J. Cereb. Blood Flow Metab. 33, 1711-1715. doi: 10.1038/jcbfm.2013.152

Yeo, R. W., Lai, R. C., Zhang, B., Tan, S. S., Yin, Y., Teh, B. J., et al. (2013). Mesenchymal stem cell: an efficient mass producer of exosomes for drug delivery. Adv. Drug Deliv. Rev. 65, 336-341. doi: 10.1016/j.addr.2012. 07.001

Yi, X., Wei, X., Lv, H., An, Y., Li, L., Lu, P., et al. (2019). Exosomes derived from microRNA-30b-3p-overexpressing mesenchymal stem cells protect against lipopolysaccharide-induced acute lung injury by inhibiting SAA3. Exp. Cell Res. 383:111454. doi: 10.1016/j.yexcr.2019.05.035

Yuan, O., Lin, C., Wagner, J., Archard, J. A., Deng, P., Halmai, J., et al. (2019). Exosomes derived from human primed mesenchymal stem cells induce mitosis and potentiate growth factor secretion. Stem Cells Dev. 28, 398-409. doi: 10. 1089/scd.2018.0200

Zhang, J., Li, S., Li, L., Li, M., Guo, C., Yao, J., et al. (2015). Exosome and exosomal MicroRNA: trafficking, sorting, and function. Genomics Proteomics Bioinform. 13, 17-24. doi: 10.1016/j.gpb.2015.02.001

Zhang, W., Wang, Y., and Kong, Y. (2019). Exosomes derived from mesenchymal stem cells modulate miR-126 to ameliorate hyperglycemia-induced retinal inflammation via targeting HMGB1. Invest. Ophthalmol. Vis. Sci. 60, 294-303. doi: $10.1167 /$ iovs.18-25617
Zhang, Y., Chopp, M., Liu, X. S., Katakowski, M., Wang, X., Tian, X., et al. (2017). Exosomes derived from mesenchymal stromal cells promote axonal growth of cortical neurons. Mol. Neurobiol. 54, 2659-2673. doi: 10.1007/s12035-0169851-0

Zhao, W., Ren, G., Zhang, L., Zhang, Z., Liu, J., Kuang, P., et al. (2012). Efficacy of mesenchymal stem cells derived from human adipose tissue in inhibition of hepatocellular carcinoma cells in vitro. Cancer Biother. Radiopharm. 27, 606-613. doi: 10.1089/cbr.2011.1150

Zscharnack, M., Hepp, P., Richter, R., Aigner, T., Schulz, R., Somerson, J., et al. (2010). Repair of chronic osteochondral defects using predifferentiated mesenchymal stem cells in an ovine model. Am. J. Sports Med. 38, 1857-1869. doi: 10.1177/0363546510365296

Zucca, E., Corsini, E., Galbiati, V., Lange-Consiglio, A., and Ferrucci, F. (2016). Evaluation of amniotic mesenchymal cell derivatives on cytokine production in equine alveolar macrophages: an in vitro approach to lung inflammation. Stem Cell Res. Ther. 7:137. doi: 10.1186/s13287-016-0398-9

Conflict of Interest: The authors declare that the research was conducted in the absence of any commercial or financial relationships that could be construed as a potential conflict of interest.

Copyright (c) 2021 Harman, Marx and Van de Walle. This is an open-access article distributed under the terms of the Creative Commons Attribution License (CC BY). The use, distribution or reproduction in other forums is permitted, provided the original author(s) and the copyright owner(s) are credited and that the original publication in this journal is cited, in accordance with accepted academic practice. No use, distribution or reproduction is permitted which does not comply with these terms. 